\title{
THE 1107 MANUAL FOR PHYSICS CHAIN, A REACTOR ANALYSIS CODE
}

\section{and \\ DEVELOPMENT \\ PEPORT}

E. L. KELLEY, JR.

D. R. MARR

APRIL, 1967
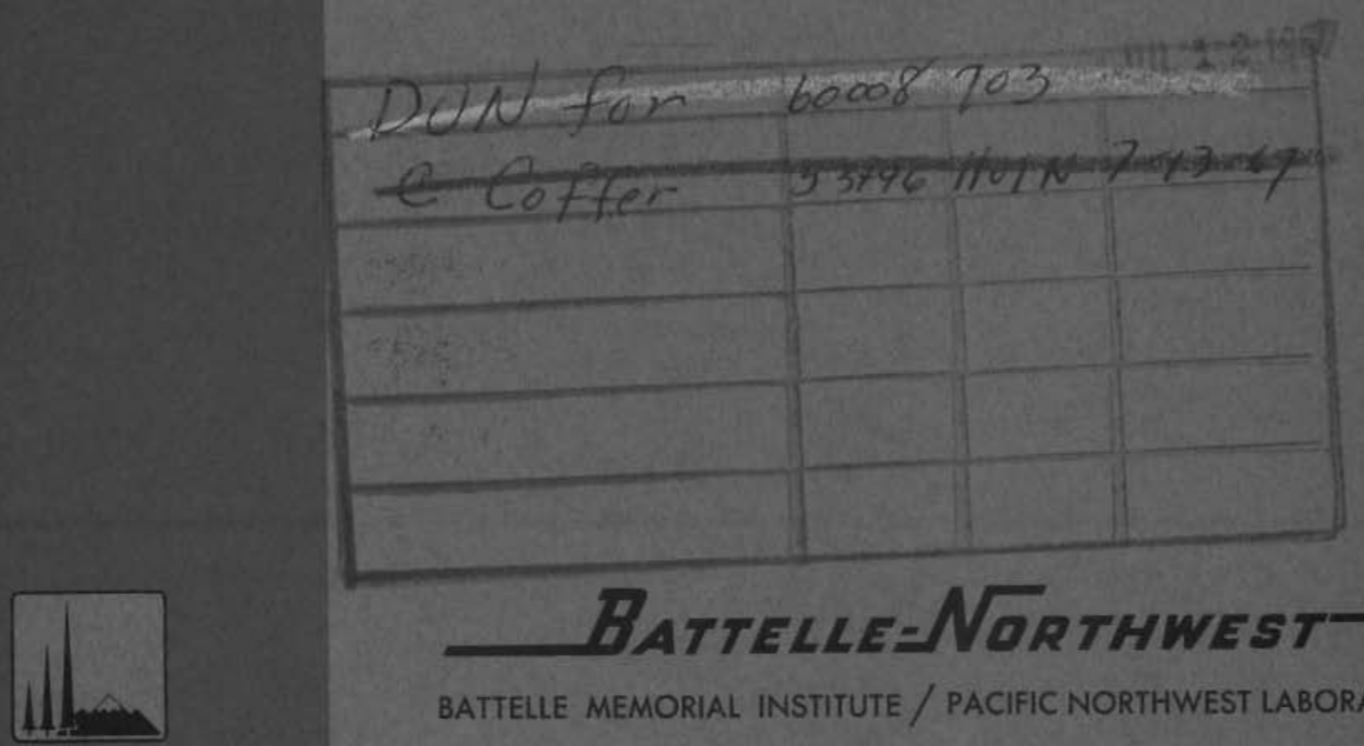

BatTelle=NoRthWEst

BATTELLE MEMORIAL INSTITUTE / PACIFIC NORTHWEST LABORATORY 


\title{
LEGAL NOTICE
}

This report was prepared as an account of Government sponsored work. Neither the United States, nor the Commission, nor any person acting on behalf of the Commission:

A. Makes any warranty or representation, expressed or implied, with respect to the accuracy, completeness, or usefulness of the information contained in this report, or that the use of any information, apparatus, methcd, or process disclosed in this report may not infringe privately owned rights; or

B. Assumes any liabilities with respect to the use of, or for damages resulting from the use of any information, apparatus, method, or process disclosed in this report.

As used in the above, "person acting on behalf of the Commission" includes any employee or contractor of the Commission; or employee of such contractor, to the extent that such employee or contractor of the Commission, or employee of such contractor prepares, disseminates, or provides access to, any information pursuant to his employment or contract with the Commission, or his employment with such contractor.

\author{
PACIFIC NORTHWEST LABORATORY \\ RICHLAND, WASHINGTON \\ operated by \\ BATTELLE MEMORIAL INSTITUTE \\ for the
}

UNITED STATES ATOMIC ENERGY COMMISSION UNDER CONTRACT AT(45-1)-1830 
33679000605693

\author{
BNWL-113 \\ UC-80 Reactor TechnologV \\ THE 1107 MANUAL FOR PHYSICS CHAIN, \\ A REACTOR ANALYSIS CODE \\ By

$$
\begin{gathered}
\text { E. L. Kelley, Jr. } \\
\text { D. R. Marr }
\end{gathered}
$$ \\ Theoretical Physics \\ FFTF Reactor Physics Section
}

April,1967

FIRET ONRESTRICTEN

Distribution made MAYI2' 67

PACIFIC NORTHWEST LABORATORY

RICHLAND, WASHINGTON 


$$
\begin{gathered}
\text { Printed in the United States of America } \\
\text { Available from }
\end{gathered}
$$

Clearinghouse for Federal Scientific and Technical Information National Bureau of Standards, U.S. Department of Commerce Springfield, Virginia 22151

Price: Printed Copy $\$ 3.00$; Microfiche $\$ 0.65$ 
TABLE OF CONTENTS

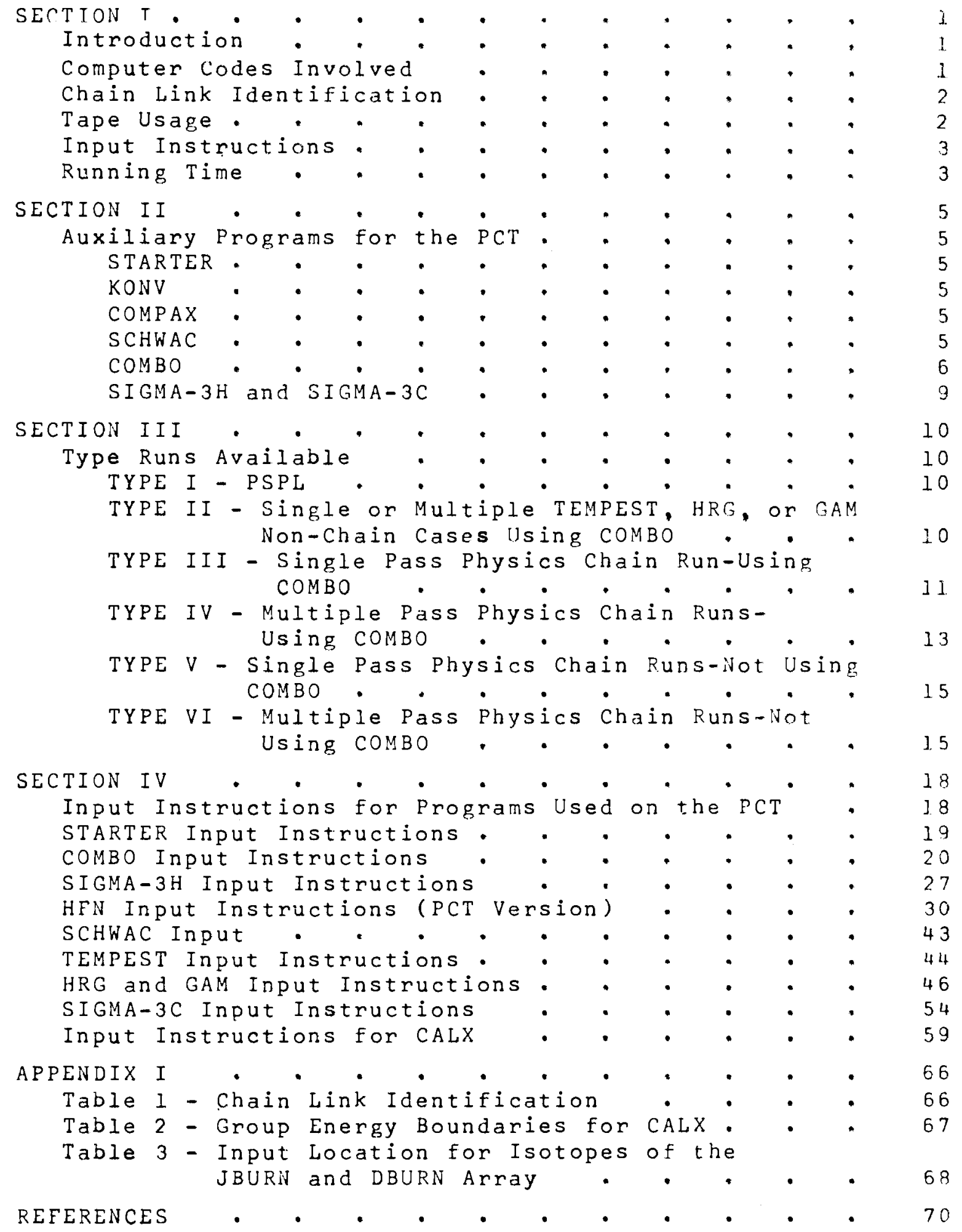


THE 1107 MANUAL FOR PHYSICS CHAIN, A REACTOR ANALYSIS CODE

$$
\begin{gathered}
\text { E. L. Kelley } \\
\text { D. R. Marr }
\end{gathered}
$$

SECTION I

Introduction to the Physics chain

PHYSICS CHAIN is an automated collection of codes that first prepare cross sections and then use those cross sections to do a o-d burnup or a l-d multigroup, multiregion diffusion calculation.

PHYSICS CHAIN enables the user to analyze a reactor or cell type problem. This is accomplished in three steps: (1) A neutron flux spectrum for the reactor (cell), or perhaps a separate spectrum for each region of the reactor (cell), is generated from a reference set of cross sections on a relatively fine energy mesh, and a set of microscopic group cross sections is averaged over this spectrum; (2) These data group cross sections are used as input to special programs that generate data tapes; (3) these data tapes are used by the computer programs that solve multigroup, multiregion diffusion or burnup problems. These three major steps are accomplished with one computer pass. Those familiar with computer use can readily appreciate the drastic reduction of man hours and machine time from that ordinarily involved in running each program separately to accomplish its portion of the problem, in addition to the reduction of errors due to excessive card handling and input conversion. At the time of this printing there exist two separate Physics Chains-one for the IBM 7090, see HW-80968, and one for the UNIVAC 1107 . This document describes the UNIVAC 1107 Physics Chain.

\section{Computer Codes Involved}

The programs on the Physics Chain Tape (PCT) used to generate spectrum averaged isotope cross section databy 
energy groups are TEMPEST, (1) HRG, (2) and GAM, (3) with TEMPEST calculating cross sections for the thermal group (energies up to $2.0 \mathrm{eV}$ ) and HRG or GAM calculating cross sections for the epithermal groups (energies from $0.414 \mathrm{eV}$ to $10 \mathrm{MeV}$ ). Cross sections generated by these programs are written to a separate tape and make up the TAM Library which is used by the programs SIGMA-3H and SIGMA-3C.

Upon completion of the TAM Library, control is shifted to either SIGMA-3H or SIGMA-3C. If SIGMA-3H is called it will read the TAM Library along with regular input and make up an HFN Data Tape. Upon completion of the HFN Data Tape, SIGMA-3H calls program $H F N(4)$ as the next link of the chain. HFN reads the data tape produced by SIGMA-3H along with regular input information and performs the necessary diffusion theory calculations. The HEN program in this case is the final link of the chain, and when the desired calculations are completed the problem is terminated. If SIGMA-3C is called the same procedure follows except that a CALX Data Tape is made and Program CALX(5) is called as the next chain link rather than HFN. In this case there are additional options which depend on the type problems being run with CALX.

Chain Link Identification

The chain link identification number for any program that might be used on a Physics chain run may be found on Table 1, Appendix I, of this manual.

\section{Tape Usage}

Various library and data tapes are used when running the Physics Chain and are referred to throughout this manual. It is felt that information here as to their usage might eliminate later confusion. 
A Composite Library Tape (CLT) is used by the PCT and contains the basic cross section libraries that were mentioned previously. There are three of these cross section libraries on a particular CLT, two in binary form and one in decimal. The first, a binary, is used by program TEMPEST and contains basic isotope cross section information for use in calculating the spectrum for the thermal group. The second, also binary, is used by HRG or GAM and contains basic isotope cross section information for use in calculating the spectrum for the epithermal energies. The third, a decimal library, is used by SIGMA-3H or SIGMA-3C for coordinating and analyzing information from TEMPEST and HRG or GAM output that is written to the TAM Library. More detailed description is found in the SIGMA-3 Library document. ( 7 )

As mentioned previously, the TAM Library tape generated by programs TEMPEST and GAM Or TEMPEST and HRG contains the spectrum averaged isotopic group cross sections for the problem or region of the problem being analyzed. Information is read from this library and used by codes SIGMA-3H or SIGMA-3C for making up the HFN or CALX Data Tapes. As their names imply these data tapes contain input data for programs HFN and CALX.

\section{Input Instructions}

Specific input instructions for each program that is to be used when running a PCT may be found in section IV of this manual. Information concerning input flow and tapes required for a given type problem may be found in section II. Running Time

Running time for the 1107 PHYSICS CHAIN is approximately $10 \%$ less than that of the 7090 PHYSICS CHAIN. However, since the EXEC MONITOR provides for simultaneous operation of 
parasites (printer, card reader, typewriter, punch, data line), running times may vary as much as $20 \%$ under adverse conditions. 
SECTION II

Auxiliary Programs for the PCT

This section deals with programs that take care of the chain "housekeeping," and other necessities such as permitting operation with standardized input, controlling type run to be made and monitoring when particular links are to be called. Program use of these codes is described in this section, with instructions when and when not to use them.

\section{Program STARTER}

The purpose of this code is to copy the appropriate libraries onto drum from which files can be more readily accessed in multiple pass problems. STARTER also determines the nature of the run, whether a simulated chain run or a PSPL (Pseudo Special Procedures Library) run, and arranges the $I / \theta$ table accordingly.

Program KONV

Prograr KONV zonverts HRG or GAM type CLTs from the IBM 7090 format to the UNIVAC 1107 format.

Program COMPAX

This program compacts the records on a CLT into 5000 word records consequently reducing the tape to drum time from approximately 1 minute to approximately 8 seconds. Program compax is kept in absolute form in the first file of the program tape. It requires no card input. The CLT to be compacted should be mounted on logical tape $A$ and a tape on which the compacted version can be written should be mounted on logical tape $B$.

Program SCHWAC

Program SCHWAC is an auxiliary program to be used with HFN to reduce the number of regions through homogenization. SCHWAC 
is called into memory after an HFN run which gererates the necessary average fluxes for the many region problem. SCHWAC then flux weight averages the HFN neutron parameters for the desired configuration.

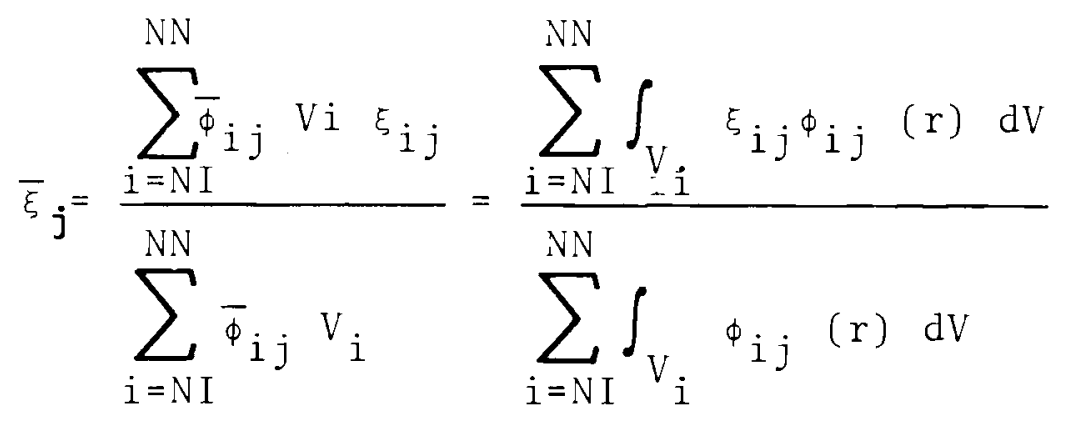

where

$\xi$ parameter to be averaged in the $j^{\text {th }}$ group

NI index of region at which to start average

$N N$ index of last region to be put in average

$v_{i}$ volume of the $i^{\text {th }}$ region

$\vec{\Phi}_{i}$ is the average $f l u x$ in the $i^{\text {th }}$ region.

Rerunning of HFN with the above homogenized parameters is

permitted.

Program comBo

Introduction

Program COMBO is a computer code which has been written primarily to simplify input to the PHYSICS CHAIN. Subroutine LISTIV ${ }^{(6)}$ is used as a means of getting input into the TEMPEST and HRG or GAM codes now used on the PHYSICS CHAIN Tapes. By using this program one may eliminate most of the input redundancy due to former input requirements, at the same time letting the program take care of some of the "bookkeeping" that is presently required by $H R G$ and GAM. 
Isotopes used in calculating the spectrum need only be referred to by their SIGMA-3 Library (7) identification numbers and may be listed in random order. COMBO will take these isotopes, assign corresponding TEMPEST and HRG or GAM identification numbers to the isotopes, and arrange the numbers in ascending order as required by HRG and GAM.

After all the input data for TEMPEST and HRG or GAM have been read and modified to meet the requirements of these programs, СомBO then writes these data to the Chain Data Tape (special drum location) in record order corresponding to the program for which the data are used. This process is followed for as many passes through TEMPEST and HRG or GAM as desired by the user. Further information on multiple pass procedures may be found in this section under the heading Code Restrictions, or in section II for the particular type problem being run.

When all comBo data for the run have been read and written to the Chain Data Tape or drum, the tape or drum is rewound and COMBO calls the next link on the chain as specified by input (see combo Input Instructions).

Options Available

Modifications have been made to this program that enable the user to run single or multiple cases of individual codes using the LISTIV input formats. This means that COMBO is available not only for complete chain runs, but may be used for $H R G$, TEMPEST, or GAM runs only.

In making runs for a single code it is necessary to supply only the input pertinent to that code. A column labeled CODE has been added to the COMBO input instructions. In this column, for each input location, there will be either a $T$ or an $H$, both a $T$ and an $H$, or neither. All input is necessary for normal chain runs. However, for single or multiple TEMPEST runs, only those entries that have a $T$ under the coDE column are necessary. 
For single or multiple HRG or GAM runs, only the entries that have an $H$ are necessary.

Code Restrictions

1. Library Sources

When making a run of any type that employs the use of COMBO, a CLT must be mounted that contains the Library or Libraries for that particular type run. Example: If an HRG case is to be run, a CLT containing the HRG Library must be used-a regular HRG Library Tape is not sufficient.

2. Link Specification

The user must specify the link to call after comBo has finished arranging input according to the program to be run. This is necessary when running a single TEMPEST, HRG, or GAM case as well as with regular Chain Runs. See Location 15 of comBo Input Instructions.

3. Multi-region Reactor Type Problems

When running a reactor type problem involving more than one region, it is usually necessary to make a pass through TEMPEST and HRG or GAM for each region of the problem. By means of infut, COMBO monitors the passes to be made and expects a separate input case for each pass.

Advantages in Using Program COMBO

Listed below are certain conveniences that are available when using a PCT that contains program COMBO.

1. Program COMBO uses input formats as specified by subroutine LISTIV.

2. COMBO does not clear memory with each case, therefore multiple TEMPEST and $H R G$ and GAM passes may be made with changes being made only to input that differs from case to case. 
3. The SIGMA-3 Library isotope identification number is sufficient for identifying isotopes used in spectrum calculations by TEMPEST and HRG or GAM. COMBO has an isotope Identification Number Library and will select the proper TEMPEST and HRG or GAM number corresponding to the. SIGMA-3 number.

4. The isotope identification numbers need not be arranged in any particular order. COMBO will select the proper HRG or GAM identification numbers and arrange these numbers in ascending order as is specified by these programs.

5. The same set of isotope densities may be used for both TEMPEST and HRG or GAM isotopes unless otherwise specified.

Program SIGMA-3H and SIGMA-3C

Programs SIGMA- $3 H$ and SIGMA-3C are used on the Physics Chain to generate cross section data tapes for programs HFN and CALX. These programs read the group microscopic cross sections calculated by the thermal and epi-thermal spectrum codes and generate the HFN or CALX data tape for a particular problem.

Options are available in SIGMA-3H or SIGMA-3C that allow the user to mix isotopes and enter on the HFN or CALX data tape a mixture that may be treated as an isotope. There are provisions for generating up to $10 \mathrm{mixtures.}$ 


\section{SECTION III}

This section describes the type problems that can be run on the PHYSICS CHAIN. Listed below are the types permitted at present:

TYPE I PSPL

TYPE II Single or Multiple TEMPEST, HRG, or GAM non-chain cases using COMBO

TYPE III Single pass chain-with COMBO

TYPE IV Multiple pass chain-with cOMBO

TYPE V Single pass chain-without COMBO

TYPE VI Multiple pass chain-without COMBO

Further information concerning control flow and tapes needed for these various type runs follows in this section of the manual. TYPEI - PSPL

PSPL (Pseudo SPL) is an attempt to provide users with codes, the input to which is compatible with input to SPL codes on the IBM 7090. In each case only the specific library is copied from the CLT (if used) to the drum. The user is thus warned that even though the code will possibly transfer to another link, the library may not be available for that link.

Input should be in the following order:

\begin{tabular}{ll} 
Input to: & \multicolumn{2}{c}{ Comments: } \\
STARTER & Use Type 2 STARTER Input. \\
Applicable & Standard SPL or IBM 7090 \\
Code & deck input.
\end{tabular}

TYPE II - Single or Multiple TEMPEST, HRG, or GAM Non-Chain Cases Using COMBO

This type problem allows the user to make TEMPEST, GAM or HRG runs using the convenient LISTIN input formats. Input is submitted in accordance with COMBO input instructions. A COMBO Data Case is needed for each pass through TEMPEST, HRG, or GAM. 
Input flow should be in the following order:

Input to:

STARTER

COMBO
Comments:

Use Starter's type 2 input formats. (see STARTER Input Instructions.)

If single or multiple TEMPEST runs are being made use combo input for only those entries that have a " $T$ " under the code column. If $H R G$ or GAM is being run use only those entries that have an "H" under the code column.

TYPE III - Single Pass Physics Chain Run - Using COMBO

This type problem calls for one pass through the Physics Chain, using COMBO to generate input for TEMPEST and HRG or GAM. Program TEMPEST reads this input, along with a basic cross section library as contained on a CLT, and does a spectrum calculation for the thermal energy group. A set of thermal group cross sections are then written by TEMPEST to a TAM library and the next link, HRG or GAll, is called. Programs HRG or GAM read their COMBO generated input, along with cross sections from a Basic Library, and perform calculations for the epithermal energy groups. The epithermal group cross sections are then written to the TAM Library and the next link is called, this being either Program SIGMA-3H or SIGMA-3C. The function of these programs on the chain is to make up data tapes for programs HFN or CALX.

These data tapes consist of cross section data that has been read from the TAM Library and modified by the SIGMA-3H or SIGMA-3C codes. Upon completion of these data tapes control is passed to HFN or CALX, whichever the case might be. These programs read their input along with their respective data tapes and perform the desired calculations. 
Input flow should be in the following order:

\begin{tabular}{|c|c|}
\hline Input to: & Comments: \\
\hline STARTER & $\begin{array}{l}\text { Uses STARTER's type l input } \\
\text { formats. (See STARTER Input } \\
\text { Instructions.) }\end{array}$ \\
\hline $\begin{array}{l}\text { COMBO } \\
\text { (TEMPEST and } \\
\text { HRG or GAM) }\end{array}$ & $\begin{array}{l}\text { Prepares input for TEMPEST } \\
\text { and HRG or GAM in proper re } \\
\text { record order and calls } \\
\text { TEMPEST. TEMPEST analyzes } \\
\text { input and writes the thermal } \\
\text { output to the printer and to } \\
\text { the TAM Library. TEMPEST } \\
\text { then calls the epithermal } \\
\text { program GAM or HRG (as speci- } \\
\text { fied by input). HRG or GAM } \\
\text { analyzes input and writes } \\
\text { output to the printer and to } \\
\text { the TAM Library. The follow- } \\
\text { ing link is then called. }\end{array}$ \\
\hline $\begin{array}{l}\text { SIGMA-3H or } \\
\text { SIGMA-3C }\end{array}$ & $\begin{array}{l}\text { This link reads regular input } \\
\text { plus the cross section data from } \\
\text { the TAM Library as generated by } \\
\text { the thermal and epithermal codes. } \\
\text { Data is correlated and output } \\
\text { written to printer and to an HFN } \\
\text { or a CALX data tape. If SIGMA-3H } \\
\text { was used HFN is called. If } \\
\text { SIGMA-3C was used CALX is called. }\end{array}$ \\
\hline HFN or CALX & $\begin{array}{l}\text { Reads regular input and the HFN } \\
\text { or CALX data tape as generated by } \\
\text { SIGMA-3H or SIGMA-3C and performs } \\
\text { the desired calculations. }\end{array}$ \\
\hline
\end{tabular}


Type IV - Multiple Pass Physics Chain Runs - Using COMBO

This type run is the same as the Type III run except for the multiple pass feature. It is often desirable, especially when using HFN to analyze data for a multiregion reactor type problem, to make multiple spectrum calculations each requiring a separate pass through TEMPEST and HRG or GAM. For this type problem the thermal and epithermal codes make up a TAM Library, which is a set of thermal and epithermal cross sections for a particular spectrum. For the first repion from input supplied by the first COMBO case, read the second set of input supplied by COMBO and make a second TAM Library, this one for the second region, and so on until there exists a TAM Library for each region in this problem. These TAM Libraries are stacked one behind the other on the Drum or a tape if so desired. When the last TAM Library has been written, the Drum or Tape is rewound and the next link, SIGMA-3H or SIGMA-3C, is called. There should be a SIGMA-3H or SIGMA-3C case for each TAM Library to be analyzed. This link makes up the HFN or CALX data tape from the cross sections furnished by the TAM Libraries. This data tape contains sequentially ordered sets of cross sections, one for each TAM Library, that will be used by HFN or CALX for final calculations in the problem. When the last SIGMA-3H or SIGMA-3C case has been run control is passed to HFN or CALX, whichever the case may be. HFN or CALX reads the data tape along, with regular input and performs the desired calculations. If necessary, more than one case of $H F N$ and CALX may be run using this data tape.

In some instances when HFN is being used to analyze cells in a reactor it is desirable to combine or homogenize the cells and analyze the reactor as a whole. To accomplish this HFN analyzes each cell as a separate case and calls another link, SCHWAC. SCHWAC averages the cross section for each cell and writes the flux weight averaged cross sections to the HFN data tape as a new material. 
When each cell has been averaged or homogenized the final case of HFN does a reactor analysis using these new averaged cross sections. Input flow for this type problem should be in the following order:

Input for:

STARTER

COMBO

( TEMPEST and HRG or GAM

SIGMA-3H or SIGMA-3C

HFN Or CALX

\section{Comments}

Uses STARTER's Type 1 input formats. (See STARTER Input Instructions.)

Data for first TEMPEST and HRG pass is read in and arranged in oroper record order for these codes and written to Drum or a specified tape. Data for second TEMPEST and HRG pass is read in and analyzed in proper record order for these codes and written to the Drum, or a specified tape, behind the first set of data.

This process is followed for each region of the problem. When data for the last repion have been written, the Drum or specified tape is rewound and control is given to TEMPEST and HRG or GAM. A TAM Library is made for each set of data and these are stacked one behind thes other on the TAM Library tape. Next link is called.

This program makes an HFN or CALX Data Tape for each region using the corresponding TAM Library and repular input. There must be a sedarate SIGMA-3H or SIGMA-3C case for each TAM Library. When the last set of cross section data has been written to the HFN or CALX Data Tape, the link containing HFi or CALX is called.

This program reads regular infut along with the data tape as generated by SIGMA-3H or SIGMA-3C and performs the desired calculations. 
TYPE V - Single Pass Physics Chain Runs - Not Using COMBO

This type run is essentially the same as the Type III run except for the input formats. When making this type chain run comBo is not used, therefore, input must be in the formats as required by TEMPEST and HRG or GAM. See TEMPEST and HRG or GAM input instructions.

Input flow should be in the following order:

Input for:

STARTER

TEMPEST

HRG or GAM

SIGMA-3H or

SIGMA-3C

HFN or CALX
Comments

Uses STARTER's type I input formats. (See STARTER Input Instructions.)

TEMPEST reads input and from a basic cross section library generates thermal cross sections which are written to the TAM Library. Calls next link.

HRG or GAM reads its input and from its basic cross section library generates a set of epithermal cross sections for the problem and writes them to the TAM Library. Calls next link.

This link reads the TAM Librarv cross sections along with normal input and prepares a data tape for either HFN or CALX. Control is transferred to next link.

Reads regular input along with the data tape as generated by SIGMA-3H or SIGMA-3C and performs the desired calculations.

\section{TYPE VI - Multiple Pass Physics Chain Runs - Not Using COMBO}

This type run is the same as the Type IV run with the exception of input formats. COMBO is not employed and therefore, input must be according to the specifications of the thermal and epithermal codes used. Since multiple passes are being made, separate input for 
each region is necessary for the thermal code (TEMPEST) and the epithermal code (HRG or GAM) in a given order for each region to be analyzed. TEMPEST input for Region 1 is followed by HRG or GAM input for the same region. Next comes TEMPEST input for Region 2 , followed by HRG or GAM input for Region 2 and so on until input has been furnished for all regions or spectrums to be analyzed. TAM Libraries are generated for each spectrum and are available for later use in the chain.

Remaining input to a Type VI Physics Chain Run is the same as for a Type IV Run. There must be a SIGMA-3H or SIGMA-3C input set for each TAM Library to be analyzed.

Input flow should be in the following order:

\section{Input for:}

STARTER

TEMPEST

HRG or GAM

TEMPEST

\section{Comment}

Uses STARTER's type 1 input formats. (See STARTER Input Instructions.)

TEMPEST reads input and its basic cross section library and generates a set of thermal cross sections for the first region or spectrum. These cross sections are written to the TAM Library tape. Calls next link.

Reads input and a basic cross section library and generates a set of epithermal cross sections for the first region or spectrum. These cross sections are written behiad the thermal cross sections on the TAM Library to complete the first TAM Library. Next link is called.

Reads input for Region 2 and generates a new set of cross sections which are written to the TAM Library tape behind the first Library. 
HRG or GAM

Reads input for Region 2 and generates epithermal cross sections which are written to the TAM Library tape to complete the second Library. Calls next link.

Note: This process is continued for each region or spectrum to be analyzed by the problem, after which the TAM Library tape is rewound and the next Link on the Physics Chain is called.

$$
\begin{aligned}
& \text { SIGMA-3H or } \\
& \text { SIGMA-3C }
\end{aligned}
$$

This link analyzes the TAM Library for each repion of the problem and makes up a HFN or CALX data tape, There must be a set of input for each TAM Library to be analyzed. After all the TAM Libraries have been analyzed and HFN or CALX data tapes written, the data tapes are rewound and HFN or CALX is called.

HFN Or CALX

Reads regular input and the HFN or CALX data tape as generated by SIGMA-3H or SIGMA-3C and performs the desired calculations. 


\section{SECTION IV}

Input Instructions for Programs Used on the PCT

This section of the Physics chain manual contains specific input instructions for all auxiliary and working programs for the chain. It should be noted that programs COMBO, SIGMA-3H, SIGMA-3C, HFN and CALX use subroutine LISTIV as a means of getting input into program storage. For information concerning use of this subroutine consult the LISTIV document, BNWL-4l. 


\section{STARTER INPUT INSTRUCTIONS}

STARTER input consists of one card only. It must be one of the following two types:

\section{TYPE 1 - Chain Type (5I3 Format)}

Column

$1-3$

$4-6$

$7-9$

$10-12$

$13-15$

\section{Entry}

Logical unit for composite library tape. Suggested input: 1 (Logical Unit A). Link to call after STARTER.

1 for HFN data tape on Logical Unit $B$.

o for HFN data in a drum file.

1 for TAM Library on Logical Unit D.

o for TAM Library in a drum file.

\section{( 5 I3 Format)}

1 for CLT interlock inhibition, just rewinds when through.

0 for CLT rewind and interlock when

through reading.

TYPE 2 - Pseudo Special Procedures Library (PSPL)

Input consists of the following words in a Free field format.

RUN $x \times \ldots X$

Where the word $X X \ldots X$ is one of the following:

$\begin{array}{ll}\text { TEMPEST } & \text { SIGMA-3C } \\ \text { GAM } & \text { CALX } \\ \text { HRG } & \text { COMBO-TEMPEST } \\ \text { HFN } & \text { COMBO-GAM } \\ \text { SIGMA-3H } & \text { COMBO-HRG }\end{array}$

GAM, HRG, and TEMPEST will expect a specific library tape on logical unit $A$ and SIGMA-3H and SIGMA-3C will expect a card library. If the words [WITH] CLT are added, STARTER will copy the appropriate library from the CLT (which should be on logical unit A) to the area of the drum which the code accesses. COMBO-TEMPEST, COMBOGAM, and COMBO-HRG type runs require a CLT and hence the words [WITH] CLT are not required. 
COMBO INPUT INSTRUCTIONS

\begin{tabular}{|c|c|c|c|}
\hline Code & Format & Location & Name \\
\hline$T \cdot H$ & 2 & $1-12$ & $B C D$ \\
\hline$T, H$ & 1 & 13 & NCASE \\
\hline $\mathrm{T}, \mathrm{H}$ & 1 & 14 & NSET $* *$ \\
\hline \multirow[t]{2}{*}{$T, H$} & 1 & 15 & LINK \\
\hline & 1 & 18 & ISAME \\
\hline$T, H$ & 1 & 19 & NGP \\
\hline$T, H$ & 1 & 20 & NISO \\
\hline $\mathrm{T}, \mathrm{H}$ & 1 & $21-70$ & Iso \\
\hline \multirow[t]{2}{*}{$\mathrm{T}, \mathrm{H}$} & 0 & $71-120$ & DEN* \\
\hline & 0 & $4401-4450$ & TCON \\
\hline $\mathrm{T}$ & 0 & 121 & TEMP \\
\hline$*$ & See & tnote on $P$ & age 29 . \\
\hline$* *$ & See foo & tnote on $p$ & age 29. \\
\hline
\end{tabular}




\begin{tabular}{|c|c|c|c|c|}
\hline Code & Format & Location & Name & Remarks \\
\hline$T$ & 0 & 122 & EM IN & $\begin{array}{l}\text { Minimum energy for averaging, } \\
\text { thermal group. }\end{array}$ \\
\hline $\mathrm{T}$ & 0 & 123 & EMAX & $\begin{array}{l}\text { Maximum energy for averaging } \\
\text { thermal group. }\end{array}$ \\
\hline $\mathrm{T}$ & 0 & 124 & BUCK & $\begin{array}{l}\text { Buckling ( } B^{2} \text { for thermal group } \\
\text { only). }\end{array}$ \\
\hline$T$ & 1 & 125 & LIST & $\begin{array}{l}\text { Enter a non-zero number here } \\
\text { to get a Library listing from } \\
\text { TEMPEST. }\end{array}$ \\
\hline $\mathrm{T}$ & 1. & 126 & MTYPE & $\begin{array}{l}\text { Type of moderation (thermal) } \\
1 \text { - Heavy } \\
2-\text { Light } \\
3 \text { - Maxwellian }\end{array}$ \\
\hline $\mathrm{T}$ & 1 & 128 & NMOD & Number of moderator isotopes. \\
\hline$T, H$ & 1 & 129 & $\operatorname{DUM} 2(1) * *$ & $\begin{array}{l}\text { Should ComBo data tape be rewound? } \\
0 \text { or blank - No. } \\
1 \text { - Yes. }\end{array}$ \\
\hline $\mathrm{T}$ & 1 & $131-180$ & IMOD & $\begin{array}{l}\text { SIGMA-3 numbers for moderator } \\
\text { isotopes. (Maximum }-50)\end{array}$ \\
\hline $\mathrm{T}$ & 0 & $181-230$ & DMOD & $\begin{array}{l}\text { Densities of the moderator } \\
\text { isotopes in corresponding order } \\
\text { with IMOD array. }\end{array}$ \\
\hline $\mathrm{H}$ & 0 & 282 & GAMID & $\begin{array}{l}\text { The HRG or GAM Tape Identification } \\
\text { Number is entered here in an } \\
\text { El0.0 format. }\end{array}$ \\
\hline $\mathrm{H}$ & 1 & 283 & I CALC & $\begin{array}{l}\text { Type calculation } \\
1 \text { - Pl calc. is being used. } \\
2 \text { - Bl calc. is being used. } \\
3 \text { - Spectra is to be read in. }\end{array}$ \\
\hline $\mathrm{H}$ & 1 & 284 & ISRCE & $\begin{array}{l}\text { Source: } \\
0 \text { or Blank - Unit source in one group. } \\
1-U-233 \text { fission spectrum } \\
2-U-235 \text { fission spectrum } \\
3-\text { Pu-239 fission spectrum } \\
4-\text { Pu-24l fission spectrum } \\
5-\text { CF-252 fission spectrum } \\
6-\text { Po-Be (Whitmore - Baker) } \\
7-\text { Po-Be (Cochrane - Henry) } \\
8-\text { Ra-Be (Hill) }\end{array}$ \\
\hline
\end{tabular}

*:* See footnote on page 26. 


\begin{tabular}{|c|c|c|c|c|}
\hline Code & Format & Location & Name & Remarks \\
\hline $\mathrm{H}$ & 1 & 285 & I S G PN & $\begin{array}{l}\text { If unit source in one group, } \\
\text { specify group number here. } \\
\text { (IF ISRCE }=0 \text { ) }\end{array}$ \\
\hline H & 1 & 286 & IOUT & $\begin{array}{l}1 \text { - output to A3 and B7 (TAM LIBE.) } \\
0 \text { - output to A3 only } \\
1 \text { - output to B } 7 \text { (TAM LIBE.) only }\end{array}$ \\
\hline $\mathrm{H}$ & 1 & 287 & I AGE & $\begin{array}{l}\text { Should age calculation be made? } \\
0 \text { - No } \\
1 \text { - Yes }\end{array}$ \\
\hline $\mathrm{H}$ & 1 & 288 & MICRO & $\begin{array}{l}\text { Should microscopic cross sections } \\
\text { be calculated? } \\
0 \text { - No } \\
1 \text { - Yes }\end{array}$ \\
\hline $\mathrm{H}$ & 1 & 289 & IGEOM & $\begin{array}{l}\text { Type geometry for resonance } \\
\text { calculation } \\
1 \text { - Slab } \\
2 \text { - Cylinder } \\
3 \text { - Sphere (not available for CALX) }\end{array}$ \\
\hline $\mathrm{H}$ & 0 & 290 & STEMP & $\begin{array}{l}\text { System temperature in degrees } \\
\text { Kelvin for resonance integral } \\
\text { calculation }\end{array}$ \\
\hline $\mathrm{H}$ & 1 & 291 & I TO** & 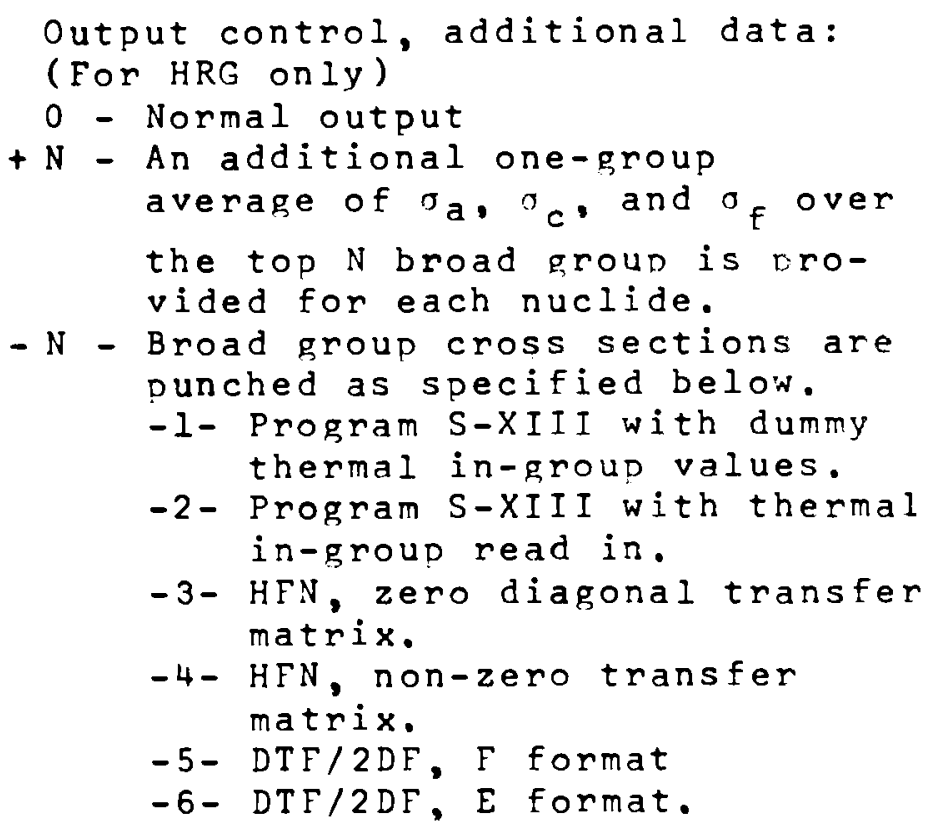 \\
\hline
\end{tabular}

*t See footnote on page 26 . 


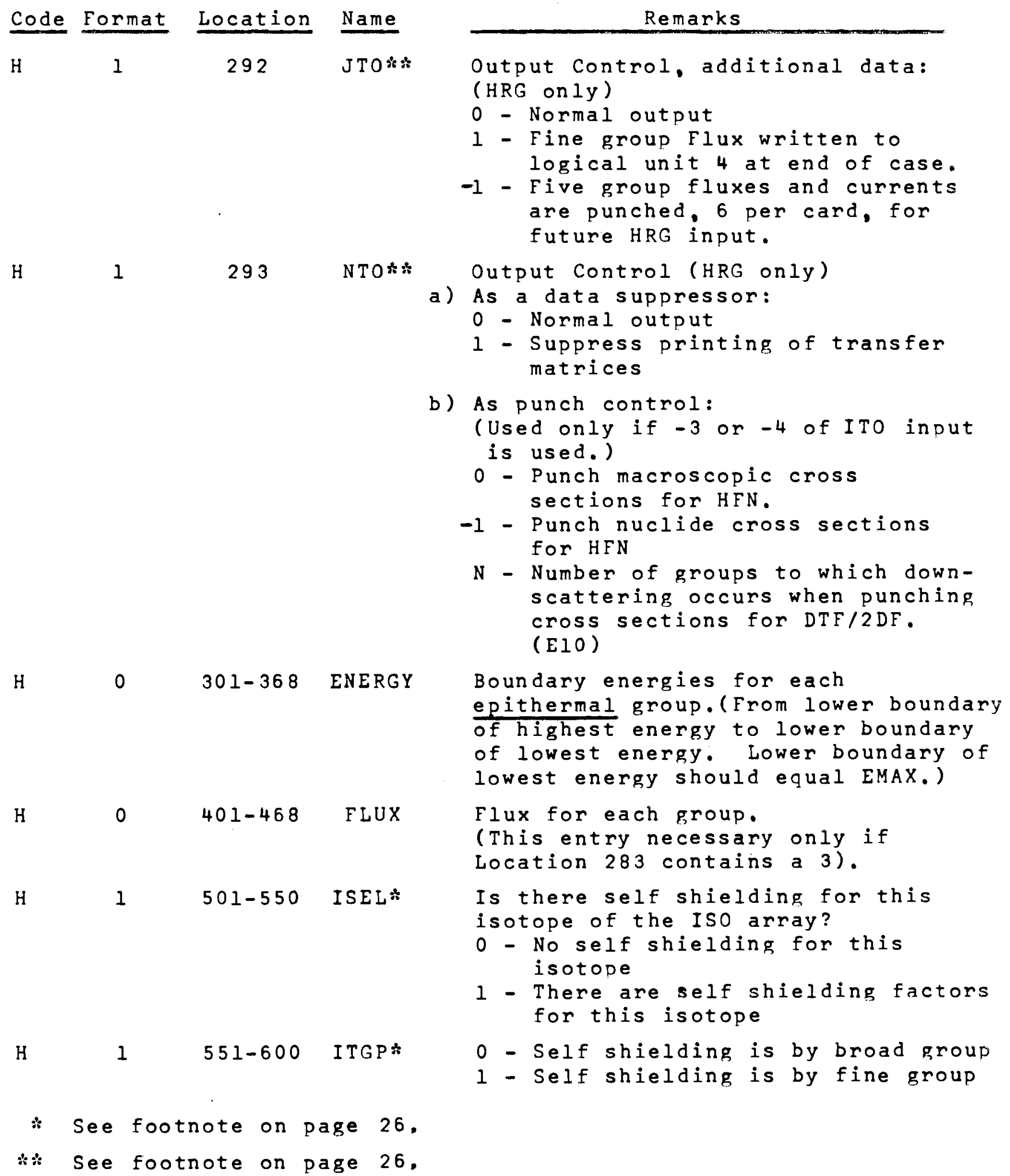




\begin{tabular}{|c|c|c|c|c|}
\hline Code & Format & Location & Name & Remarks \\
\hline \multirow[t]{4}{*}{$\mathrm{H}$} & 0 & $601-4000$ & SFACT * & $\begin{array}{l}\text { Self shielding factors for isctopes } \\
\text { as specified by the ISEL array. }\end{array}$ \\
\hline & & & & $\begin{aligned} \text { NOTE: } & \text { This is a two-dimension } \\
& \text { array and is indexed by } \\
& \text { group number and isotope } \\
& \text { number. }\end{aligned}$ \\
\hline & & & & Ex, : SFACT (NgD, Iso) \\
\hline & & & & $\begin{array}{l}\text { Factors for each group for a } \\
\text { particular isotope are read } \\
\text { in, then factors for each } \\
\text { group for the next specified } \\
\text { isotope are read in, etc. }\end{array}$ \\
\hline $\mathrm{H}$ & 1 & $4001-4050$ & IRESSS* & $\begin{array}{l}\text { Enter a } 1 \text { here for isotopes of the } \\
\text { ISO array that require resonance } \\
\text { parameters. }\end{array}$ \\
\hline $\mathrm{H}$ & 0 & $4051-4300$ & S IGMA* & $\begin{array}{l}\text { (Necessary only for those isotoces } \\
\text { requiring resonance self shieldisf. } \\
\text { one card for each isotope.) }\end{array}$ \\
\hline \multirow[t]{8}{*}{$\mathrm{H}$} & & $4051-4055$ & SI GMA-M & $\begin{array}{l}\text { Parameters for first isotope of } \\
\text { the Iso array. } \\
\text { Moderator cross section per } \\
\text { absorber atom. }\end{array}$ \\
\hline & & 4052 & S I GMA - P & $\begin{array}{l}\text { Total scatter cross section per } \\
\text { absorber atom }\end{array}$ \\
\hline & & 4053 & SIGMA-EfF & $\begin{array}{l}\text { Effective cross section for } \\
\text { unresolved resonance calculation }\end{array}$ \\
\hline & & 4054 & & Lumped nucli density per barn-cm \\
\hline & & 4055 & LBAR & LBAR in $\mathrm{cm}$ \\
\hline & & $4056-4060$ & & $\begin{array}{l}\text { Parameters for second isotope of } \\
\text { the ISo array }\end{array}$ \\
\hline & & $4061-4065$ & & $\begin{array}{l}\text { Parameters for third isotope of } \\
\text { the ISO array }\end{array}$ \\
\hline & & $4066-4101$ & & Etc. \\
\hline
\end{tabular}

* See footnote on page 26. 


\begin{tabular}{|c|c|c|c|c|}
\hline Code & Format & Location & Name & Remarks \\
\hline $\mathrm{H}$ & 1 & 4301 & I PI & $\begin{array}{l}\text { Necessary only if Pl calculation } \\
\text { is being made } \\
0 \text { - Leakage by broad group } \\
\text { l - Leakage by fine group }\end{array}$ \\
\hline H & 0 & 4302 & BKI & $\begin{array}{l}\text { Necessary for } B_{1} \text { calculations } \\
\text { only. Enter } B\left(\text { not } B^{2}\right) \text { for } \\
\text { epithermal groups only. } \\
\text { (one entry) }\end{array}$ \\
\hline $\mathrm{H}$ & 1 & 4303 & I B I & $\begin{array}{l}\text { Necessary only if Bl calculation } \\
\text { is being made. } \\
0 \text { - Bl approximation } \\
1-\text { Pl fourier transform method } \\
\left(\alpha_{n} \text { set to } 1.0\right)\end{array}$ \\
\hline H & 0 & $4304-4371$ & PLEAK & $\begin{array}{l}\text { Necessary only if Pl calculation } \\
\text { is being made. PLEAK is leakage } \\
\text { factor for groups } 1,2,3, \ldots \\
\text { NGP. In case of fine group } \\
\text { structure PLEAK entries for } 1-68 \\
\text { groups are necessary. }\end{array}$ \\
\hline - & & & & $\begin{array}{l}\text { NOTE: If leakage factors are zero, } \\
\text { put a } 0.0 \text { entry in location } \\
4304 \text { and the program will } \\
\text { automatically assign leakage } \\
\text { factors of }-1.0 \times 10-10 \text { to } \\
\text { each group. }\end{array}$ \\
\hline $\mathrm{H}$ & 1 & 4372 & NEXT & $\begin{array}{l}\text { NEXT is the link number that HGR or } \\
\text { GAM should call after each TAM } \\
\text { Library has been made. }\end{array}$ \\
\hline & & & & $\begin{array}{l}\text { NOTE: } \\
\text { the TEXT is positive, } \\
\text { rewound. If NEXT is negative } \\
\text { the TAM Library will not be } \\
\text { rewound, thus allowing the } \\
\text { Libraries to be stacked. }\end{array}$ \\
\hline $\mathrm{H}$ & 1 & 4373 & CHAIN & Tape number that Link NEXT is on. \\
\hline
\end{tabular}


* These variables are dimensioned to 50 in accord with the Iso array. Entries in these arrays must pertain to a particular isotope and therefore must correspond in position to the ISO array. Example: If $Z R$ is the $5 t h$ isotope in the Iso array, then the density of $Z R$ must be entered in the 5 th position of the DEN array. Also, if there are self shielding factors for, say U-238, for ISEL(2), and a 1 or 0 for ITGP(2), deperding, on type Group. The SIGMA array is handled similarly except there are five items entered for each isotope. $*$ Different from input as found in USER'S MANUAL FOR HFN AND
CALX CHAIN
$8)$ 


\section{SIGMA-3H INPUT INSTRUCTIONS}

\begin{tabular}{|c|c|c|c|}
\hline Format & Location & Name & Remarks \\
\hline 2 & 1 & KBCD & KBCD will be second half of HFN name. \\
\hline 2 & $2-12$ & $K B C D(2-12)$ & 66 character heading. \\
\hline 1 & 14 & NGROUP & No. of groups. Max: 20 \\
\hline 1 & 15 & NTHERM & No, of thermal groups (1). \\
\hline 1 & 16 & ISO & $\begin{array}{l}\text { No. of isotopes for which cross sec- } \\
\text { tions are wanted (does not include } \\
\text { gross fission products generated in } \\
\text { SIGMA- } 3 \text { ). }\end{array}$ \\
\hline 1 & 17 & I MIX & $\begin{array}{l}\text { No. of mixtures to mix (max. } 10 \\
\text { counting GFP's). }\end{array}$ \\
\hline 1 & 18 & NMIX & Total number of mixture components. \\
\hline 1 & 19 & L INK & 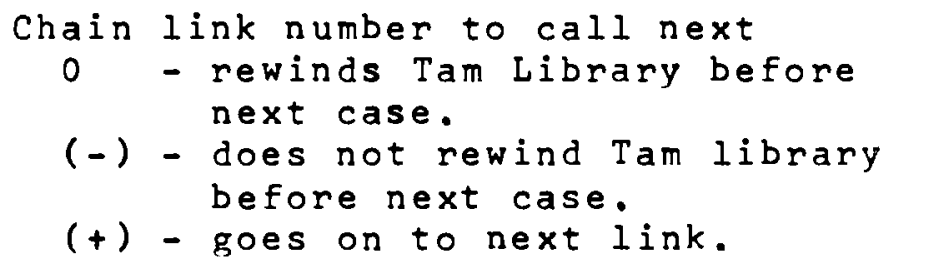 \\
\hline 1 & 20 & I TAPE & $\begin{array}{l}\text { Chain tape number on which LINK is } \\
\text { located. If zero, calls exit } \\
\text { rather than next link. }\end{array}$ \\
\hline 1 & $24-28$ & NFP & $\begin{array}{l}\text { Gross fission product control for } \\
\text { each of the five GFP tables on the } \\
\text { SIGMA-3 Library. } \\
0 \text { - No. GFP from this fission } \\
\text { table. } \\
\text { I - Mix. GFP for this fission } \\
\text { table excluding isotopes } \\
\text { specified in NISO array. } \\
\text { - } 1 \text { - } \begin{array}{l}\text { same as tl except exclude } \\
\text { mixture components also. }\end{array}\end{array}$ \\
\hline 1 & $39-138$ & N I SO & $\begin{array}{l}\text { SIGMA- } 3 \text { isotope numbers for those } \\
\text { isotopes for which cross sections } \\
\text { are wanted. }\end{array}$ \\
\hline 1 & $139-338$ & MIX & $\begin{array}{l}\text { SIGMA-3 isotope numbers for all } \\
\text { mixture components. }\end{array}$ \\
\hline 1 & 429 & MISC ( 91$)$ & $\begin{array}{l}\text { Non-zero to add this set of cross } \\
\text { sections to an existing data tape. } \\
\text { Automatically set to zero every } \\
\text { case. }\end{array}$ \\
\hline
\end{tabular}




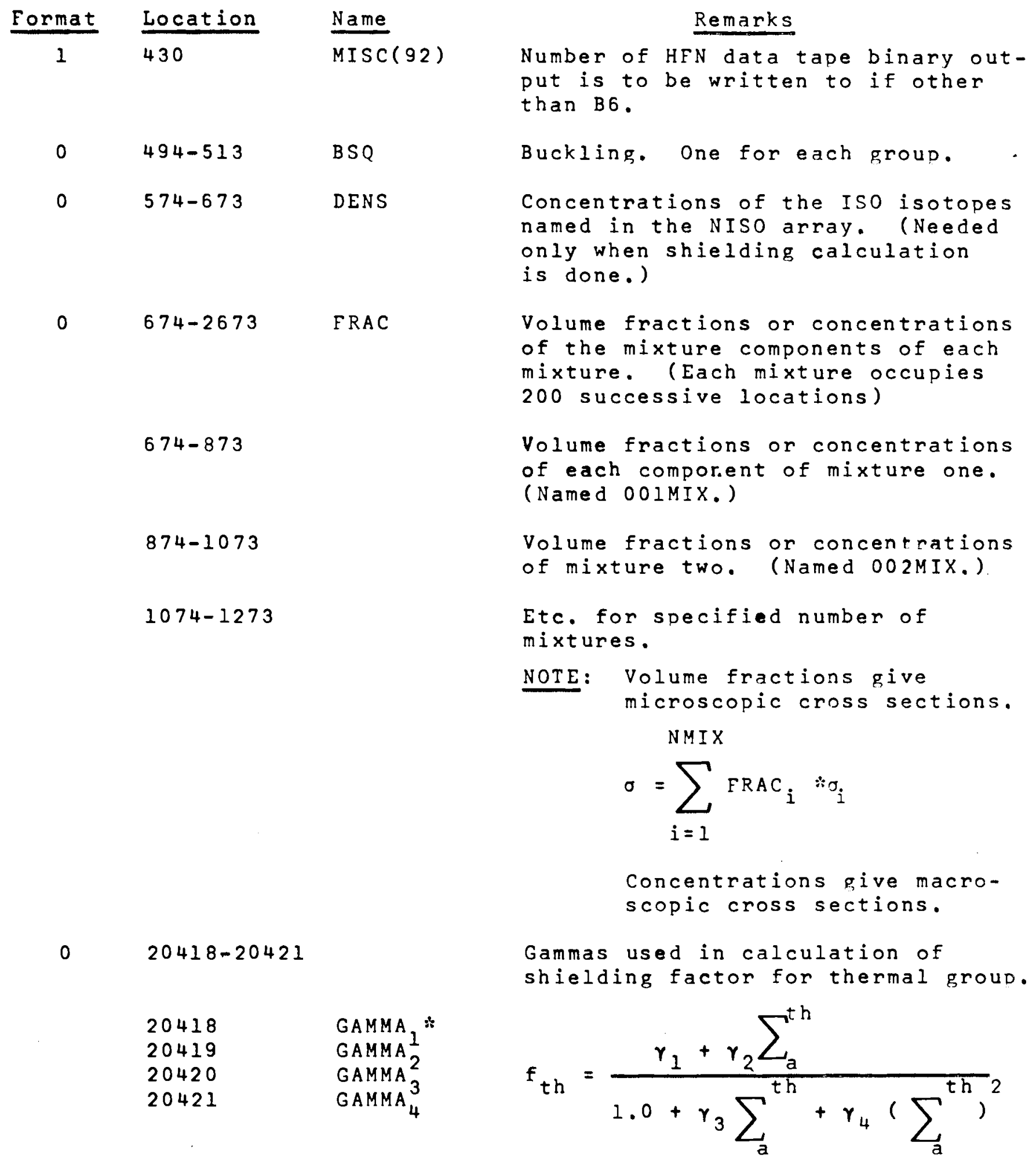

*GAMMA ${ }_{1}$ and GAMMA 5 are set to 1.0 after each case. 


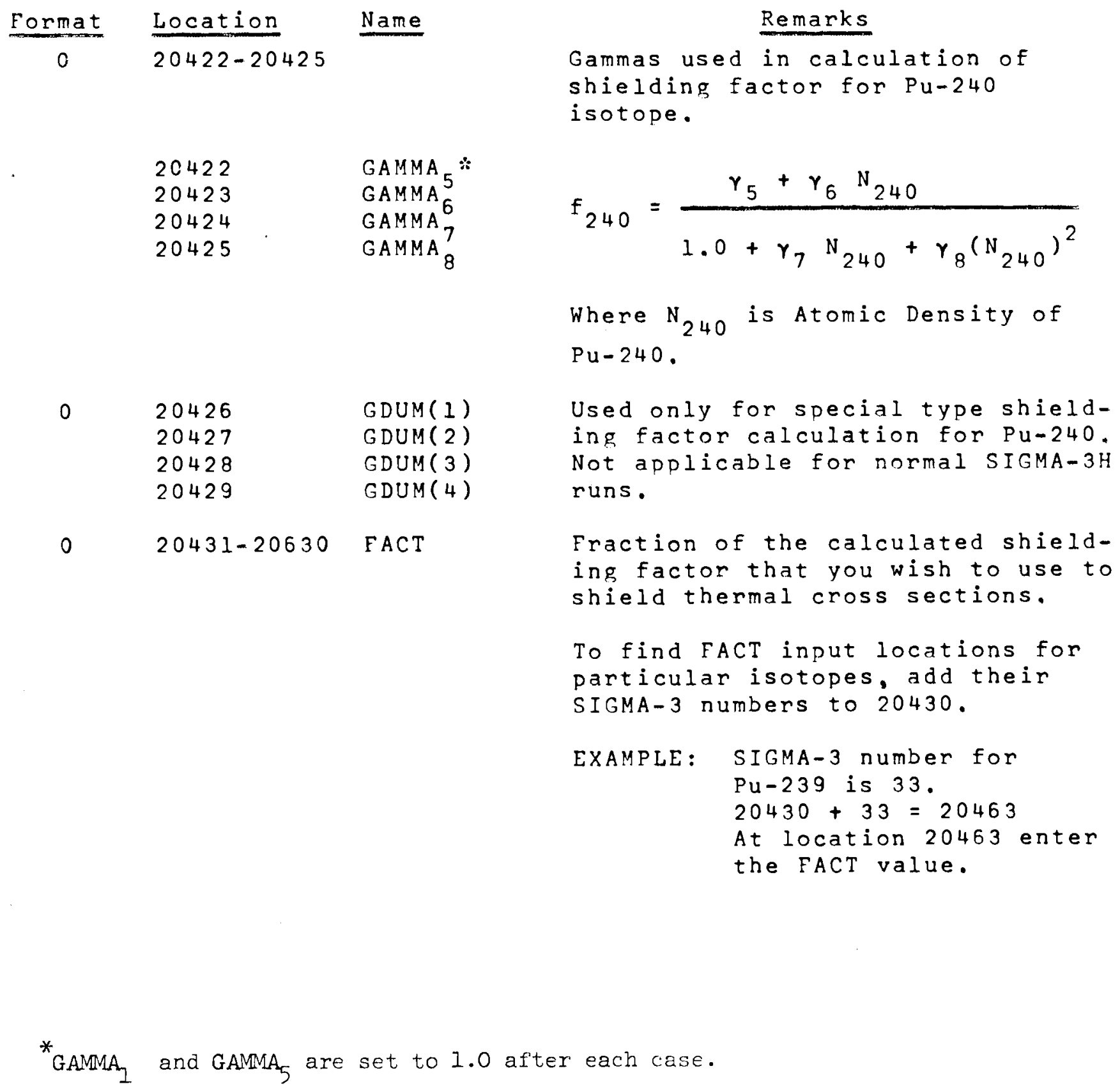


HFN INPUT INSTRUCTIONS (PCT VERSION)

\section{MISCELLANEOUS CONTROL AND TAPE INFORMATION}

\begin{tabular}{|c|c|c|c|}
\hline Format & Location & Entry & Meaning \\
\hline 1 & 1 & $20 \geq N_{1}>1$ & Number energy groups \\
\hline 1 & 2 & $\mathrm{~N}_{2}=0$ & $\begin{array}{l}\text { Scattering transfer can only take } \\
\text { neutrons from a group to the next } \\
\text { lower energy (higher indexed) group }\end{array}$ \\
\hline & & $\mathrm{N}_{1} \geq \mathrm{N}_{2}>0$ & 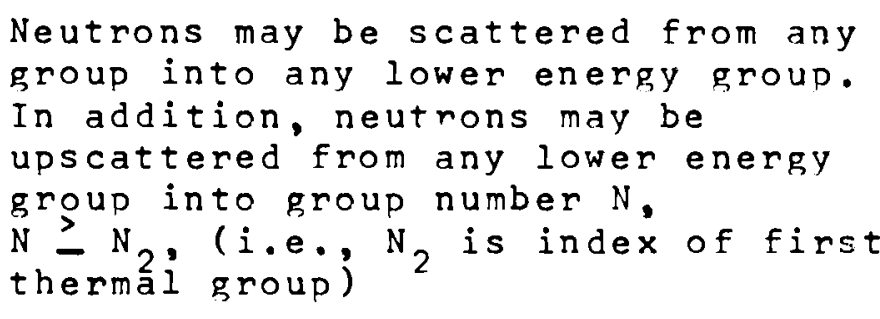 \\
\hline
\end{tabular}

Example: In a five group calculation, with two thermal groups, $\mathrm{N}_{1}=5$ and $\mathrm{N}_{2}=4$.

1

$\mathrm{N}_{3}=1$
$\mathrm{~N}_{3}=2$
$\mathrm{~N}_{4}=0$
$\mathrm{~N}_{4}>0$

All information on external sources will be input, by soace points, into locations 17882 through 19981 . This option includes the case where no external source is present.

The external source to the right of each space point, SP, is input for all points. The program will set the source to the left of the Doint. $S M_{i}$, equal to $S P_{i}$ unless a non-zero value for $S_{i}$ is input.

The external source is constant within each region. The regional values of the external source are input to locations 20195 through 20244 .

All cross section data is input from cards, and no data tape is to be generated.

Use the cross section data which is in the library at the end of this input record to update the data tape. In case data for a given group are found both on the old data tape (if any) and in the card input, the data 


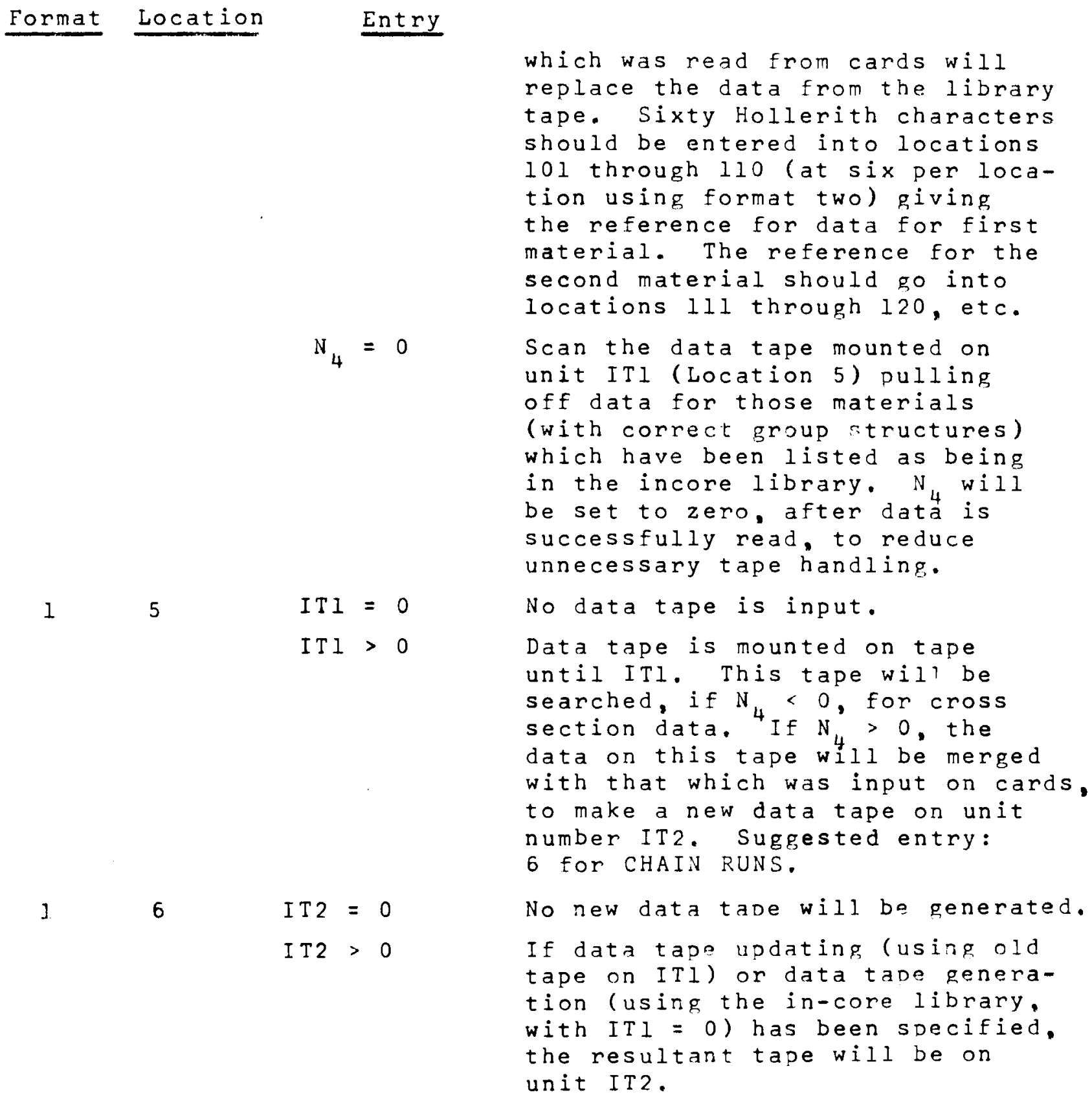

NOTE: After an updating pass has been completed, the contents of locations 5 and 6 are interchanged. Thus, in the absence of input to the contrary, successive updating passes will result in the latest data tape alternating between the two tape units. In this way, the tape may be updated and used on the input Dass immediately following the last updating pass, with HFN keeping track of the most up-to-date tape. IT 2 and ITI should always be between 5 and 10 , inclusive. 
Format Location Entry$$
1
$$

1

1

1

1

1

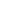

$$
100 \geq N^{*} \geq 0: *
$$

Meaning

Indicates that during the tape undating orocess, data for $N 7$ materials are to be detected. The material names are entered into the locations starting at 3752. The numbers of groups to which the effected data apply are given starting in Location 3952 . The group coupling schemes (equivalent of $N 2$ ) are given starting in Location 4052 .

Normaliy

List, in a compressed form, the data which is being added to the new data tape as it is added.

NOTE: The names, numbers of groups, group ccupling schemes, and references for all materials encountered on each tape update pass are always listed on the output. N controls listing of the actual cross sections on the tape.

$47 \quad N 47 * *$

10

$$
\begin{aligned}
& \mathrm{N}_{10}=0 \\
& \mathrm{~N}_{10} \neq 0
\end{aligned}
$$

11

$$
\begin{aligned}
& \mathrm{N}_{11}=0 \\
& \mathrm{~N}_{11} \neq 0
\end{aligned}
$$

12

$$
\begin{aligned}
& \mathrm{N}_{12}=0 \\
& \mathrm{~N}_{12}=1
\end{aligned}
$$

Link to call next. If zero reads more input.

No effect

After getting cross section from library tape, return for more input before running case. Thus, individual neutron parameters from the tape may be changed before use. $N_{10}$ will be reset to zero.

No effect

Clear all data from core immediately, then read input. Any input read in the same input record with this entry (before the next 9 card) will also be destroyed.

Save fluxes and fission densities computed for this case as a starting for the next case.

After this case is run, clear fluxes, fission densities, and pointwise external sources. Following cases start from flat (or input) flux guess. 


\begin{tabular}{|c|c|c|c|c|c|}
\hline Format & Location & & ntry & & Meaning \\
\hline & & & 2 . & CASE & SPECIFICATION \\
\hline 1 & 13 & $N_{13}$ & $\begin{array}{l}=0 \\
=1 \\
=2\end{array}$ & & $\begin{array}{l}\text { Slab geometry } \\
\text { Cylindrical geometry } \\
\text { Spherical geometry }\end{array}$ \\
\hline 1 & 14 & 50 & $\geq N R$ & $>0$ & Number of homogeneous regions \\
\hline 1 & 15 & $N_{15}$ & $\begin{array}{l}=0 \\
=1\end{array}$ & & $\begin{array}{l}\text { Compute direct flux } \\
\text { Compute adjoint function }\end{array}$ \\
\hline & & $N_{15}$ & $=2$ & & $\begin{array}{l}\text { Compute direct, adjoint functions } \\
\text { and their pradients at each point, } \\
\text { Also, compute volume integrals of } \\
\text { the form. } \\
J \phi_{i}^{+} \nabla \phi_{i} d V ; \text { and } \phi_{i} \phi_{j} d V \\
N_{15} \text { will be set to } 0 \text { at the end of } \\
\text { this sequence. }\end{array}$ \\
\hline 1 & 28 & $N_{28}$ & $=0$ & & No effect \\
\hline & & $N_{28}$ & $=1$ & & $\begin{array}{l}\text { Compute gradients of the converged } \\
\text { (direct of adjoint) fluxes. If } \\
N_{15}=2 \text {, this entry is not needed. }\end{array}$ \\
\hline 1 & 35 & $N_{35}$ & $=1$ & & $\begin{array}{l}\text { A true power density calculation } \\
\text { will be performed using the fission } \\
\text { cross sections located where the } \\
\text { in-scattering cross sections } \\
\text { normally are. }\end{array}$ \\
\hline & & $N_{35}$ & $\leq 0$ & & $\begin{array}{l}\text { A fission neutron production } \\
\text { calculation will be performed using } \\
v \Sigma_{f}\end{array}$ \\
\hline
\end{tabular}

(Data tapes made up by SIGMA-3H will have the fission cross sections in their appropriate place.)

\section{CRITICALITY SEARCH CONTROL}

When this option is exercised, HFN varies a single specified parameter in an attempt to attain a pre-specified multiplication. Each calculation involving a new value of the parameter looks, in the output, like a separate case. The difference is that, in contrast with the running of separate cases, no input is read between calculations. 


\begin{tabular}{|c|c|c|c|c|}
\hline Format & Location & & try & Meaning \\
\hline \multirow[t]{2}{*}{1} & 16 & $\mathrm{~N}_{16}$ & $=0$ & $\begin{array}{l}\text { For no search, ignore } \\
\text { Locations } 17-21\end{array}$ \\
\hline & & $N_{16}$ & $=L O C>0$ & Location of variable parameter \\
\hline \multirow[t]{2}{*}{1} & 17 & $\mathrm{~N}_{17}$ & $=0$ & No effect \\
\hline & & $\mathrm{N}_{17}$ & $>0$ & $\begin{array}{l}\text { Remake any material mixtures } \\
\text { each time the parameter is } \\
\text { varied. }\end{array}$ \\
\hline 1 & 18 & $N_{18}$ & $>2$ & $\begin{array}{l}\text { Maximum number of calculations } \\
\text { to be performed in the attempt } \\
\text { reproduce the desired multipli- } \\
\text { cation. }\end{array}$ \\
\hline 0 & 19 & $\mathrm{k}$ & & Desired multiplication \\
\hline 0 & 20 & $\mathrm{dk}$ & & $\begin{array}{l}\text { Accuracy to which } k \text { must be } \\
\text { reproduced on a successful } \\
\text { criticality search }\end{array}$ \\
\hline \multirow[t]{2}{*}{0} & 21 & $(\Delta k)$ & -1 & $\begin{array}{l}\text { Estimate of parameter change } \\
\text { necessary to increase the } \\
\text { calculated } k \text { by lo. This number } \\
\text { is used only to form an estimate } \\
\text { of the parameter, for use in the } \\
\text { second calculation, using the } \\
\text { results of the first. }\end{array}$ \\
\hline & & 4 & DETECTOR & RAVERSE CALCULATION \\
\hline \multirow[t]{3}{*}{1} & 29 & $\mathrm{~N}_{29}$ & $=0$ & $\begin{array}{l}\text { Do not normalize computed } \\
\text { activities. }\end{array}$ \\
\hline & & $\mathrm{N}_{29}$ & $>0$ & $\begin{array}{l}\text { Normalize each traverse to } 1.0 \\
\text { at HFN mesh point Number } \mathrm{N}_{29} \text {. }\end{array}$ \\
\hline & & $-\mathrm{N}_{29}^{\prime}$ & $<0$ & $\begin{array}{l}\text { Normalize all trayerses so that } \\
\text { the activity for traverse } \\
\text { Number l is unity at mesh point } \\
\text { Number N } 29 \text {. The same normalizing } \\
\text { factor will be used on all traverses. }\end{array}$ \\
\hline 1 & 30 & Not & used & \\
\hline 1 & 31 & $\mathrm{~N}_{31}$ & $\geq 0$ & $\begin{array}{l}\text { Number of traverses } N_{3 J} \leq 10 ; \text { also } \\
N_{31}:(\text { No. groups }) \leq 100 .\end{array}$ \\
\hline
\end{tabular}


Form

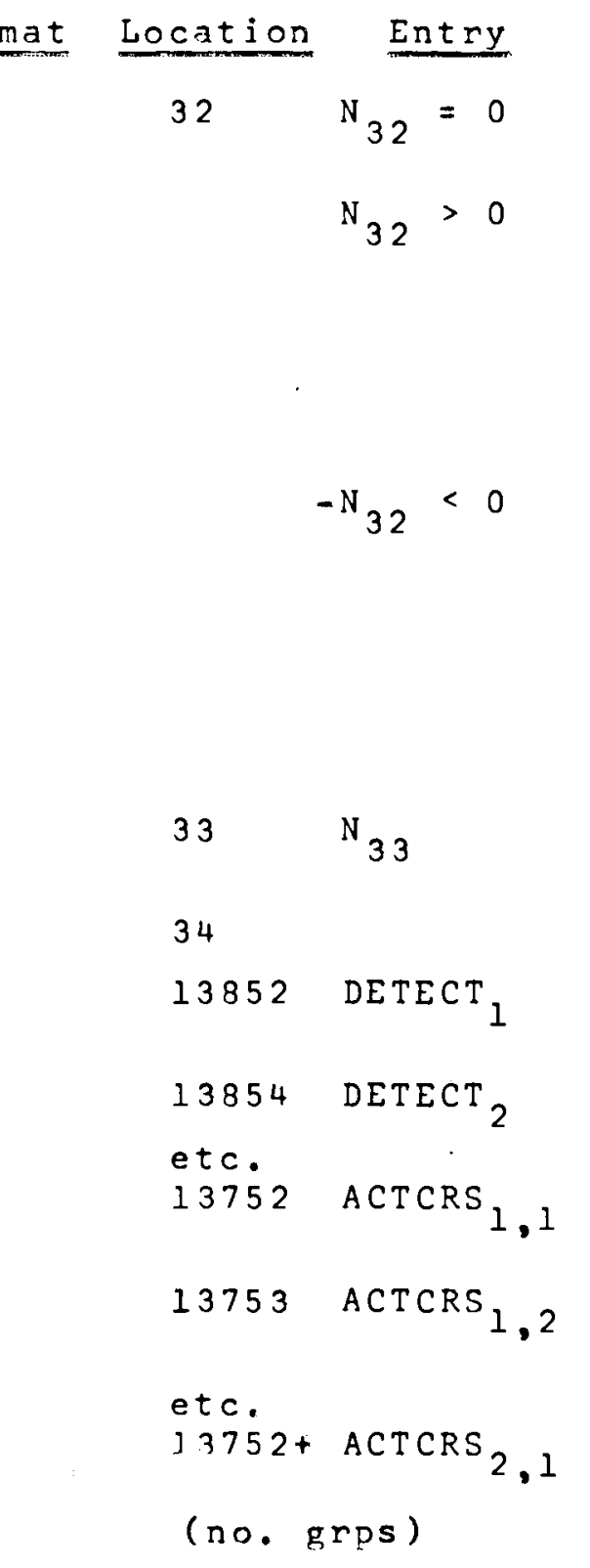

1

1

2

2

0

0

0

0

42

$A=0.0$

\begin{abstract}
Meaning
Traverse ratios, for first traverse, will not be computed.

At each mesh point, compute the activity ratio for Traverse 1 :
\end{abstract}

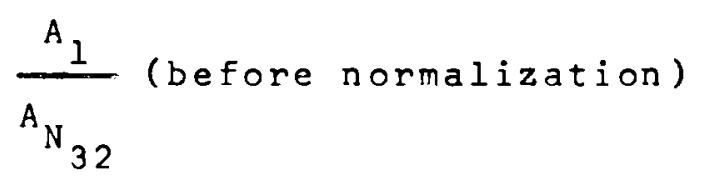

At each mesh point, compute the activity fraction for Traverse 1:

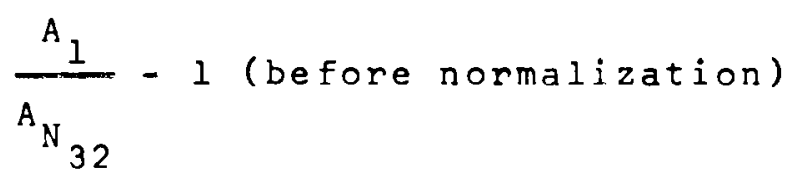

Same logic as Location 32, except pertains to traverse Number 2 .

etc.

12 Hollerith name for first detector material

12 Hollerith name for second detector material

Group one activation cross section for detector type one.

Group two activation cross section for detector type one.

Group one activation cross section for detector type two.

5. OUTPUT CONTROL OPTIONS

Flux and Power Normalization

Normalize "power" (fission neutron production rate) so that averapo over core region(s) is 1.0 , for output listing. 
Format Location Entry

$$
A>0
$$

1

$$
43 \quad N_{43}=0
$$$$
\mathrm{N}_{43}>0
$$

1

$44 \quad \mathrm{~N}_{44}$
Meaning

Normalize core power to total output of A megawatts (for purpose of converting from neutrons to $M W, H F N$ assumes $v=2.46$, with $200 \mathrm{MeV}$ per fission).

Normalize fluxes, for output, to be consistent with the power

Normalize flux, group $\mathrm{N}_{43}$, to unity at spatial mesh point number $\mathrm{N}_{44}$.

Mesh point number for flux normalization.

6. ITERATION CONTROLS

1

0

$57 \quad$ EPSK

0
Maximum number of iterations allowed. Set to 100 if not input. Suggested input: none.

Convergence criterion. The problem is assumed to have converged if the fractional difference between system eigenvalues on two successive iterations is less than EPSK. Set to 10-7 if no input. If set negative, this convergence test is bypassed forcing HFN to try for flux convergence. Suggested input: none.

Convergence criterion. The maximum fractional change in flux at any point, in any group, on two successive iterations must be less than EPSPHI for convergence. Set to $10^{-4}$ if no input. If set negative, this convergence test is bypassed forcing HFN to try for eigenvalue convergence. Sugpested input: none. 
7. OUTPUT LIST SUPPRESSION

Suppress Selected Portions of Output by Entering

a Non-zero Number in Locations Indicated

\begin{tabular}{|c|c|c|c|}
\hline Format & \multicolumn{2}{|c|}{ Location } & Meaning \\
\hline 1 & \multicolumn{2}{|l|}{62} & Transfer matrices \\
\hline 1 & \multicolumn{2}{|l|}{63} & Few group parameters \\
\hline 1 & \multicolumn{2}{|l|}{64} & Pointwise flux and fission density \\
\hline 1 & \multicolumn{2}{|l|}{65} & $\begin{array}{l}\text { Calculated reactivity as a function } \\
\text { of iteration, except final iter- } \\
\text { ation (neg. entry suppresses all } \\
\text { reactivities). }\end{array}$ \\
\hline 1 & \multicolumn{2}{|l|}{66} & $\begin{array}{l}\text { Average fluxes, fission densities, } \\
\text { and leakage cross sections computed } \\
\text { therefrom. }\end{array}$ \\
\hline 1 & \multicolumn{2}{|l|}{67} & Pointwise gradient \\
\hline 1 & \multicolumn{2}{|l|}{68} & Perturbation integrals \\
\hline 1 & \multicolumn{2}{|l|}{69} & $\begin{array}{l}\text { Direct-adjoint flux gradient } \\
\text { product (point- and group-wise). }\end{array}$ \\
\hline 1 & \multicolumn{2}{|l|}{70} & $\begin{array}{l}\text { Direct-adjoint flux product } \\
\text { (point-and group-wise). }\end{array}$ \\
\hline 1 & \multicolumn{2}{|l|}{71} & All traverse output \\
\hline 1 & \multicolumn{2}{|l|}{72} & $\begin{array}{l}\text { Flux adjoint product traverse } \\
\text { only }\end{array}$ \\
\hline 1 & \multicolumn{2}{|l|}{73} & Average traverse activity \\
\hline 1 & \multicolumn{2}{|l|}{74} & Unnormalized traverse activity \\
\hline 1 & \multicolumn{2}{|l|}{75} & Normalized traverse activity \\
\hline 1 & \multicolumn{2}{|l|}{76} & Traverse ratio data \\
\hline 1 & \multicolumn{2}{|l|}{77} & $\begin{array}{l}\text { Albedoes, region radii, } \\
\text { calculation description }\end{array}$ \\
\hline & 8. I & INITIAL GUESSES & FOR FLUX, FISSION DENSITY \\
\hline Format & Location & Entry & Meaning \\
\hline 0 & 10602 & $\operatorname{FLUX} x_{1} * *$ & $\begin{array}{l}\text { Estimate of group one flux, at } \\
\text { first mesh point }\end{array}$ \\
\hline 0 & 10603 & $F \operatorname{LUX}_{2}$ & $\begin{array}{l}\text { Estimate of proup one flux at } \\
\text { second mesh point }\end{array}$ \\
\hline
\end{tabular}


Format Location Entry Meaning

NOTE: If a total of $N$ mesh intervals have been specified in the HFN input, then group one flux estimates are input to locations 10602 through $10602+(\mathrm{N}+3)-1$. ( $N+3$ points are used, after insertion of an extra point at each outside boundary.) Group two fluxes go from locations 10602 t $(N+3)$ through $10602+(N+3)-1$. Flux estimates for other groups follow, in a similar manner.

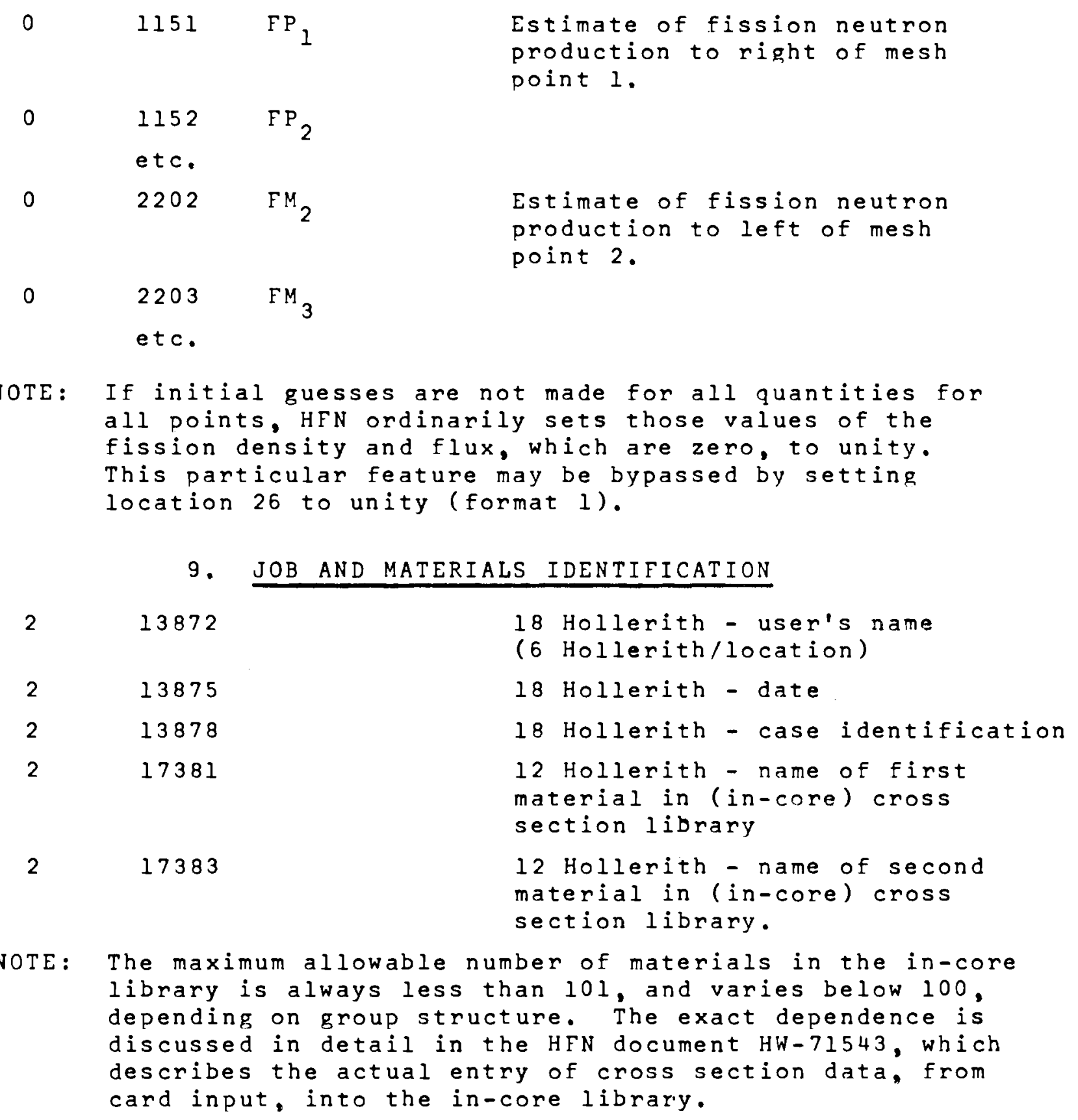


10. REGION SPECIFICATIONS

\begin{tabular}{|c|c|c|}
\hline Format & Location & Entry \\
\hline 0 & 17781 & $\mathrm{R}_{0}$ \\
\hline 0 & 17782 & $R_{1}$ \\
\hline 0 & 17783 & $\mathrm{R}_{2}$ \\
\hline 0 & 17731 & $\pm E_{1}$ \\
\hline 0 & 1.7732 & $\pm \mathrm{EN}_{2}$ \\
\hline 0 & 17733 & $\pm \mathrm{EN}_{3}$ \\
\hline
\end{tabular}

Meaning

Inside radius of inner region

Outside radius, region 1

Outside radius, region 2 , etc.

Number of mesh intervals in

region 1. This does not include the extra mesh interval inserted near left boundary.

Number of mesh intervals in region 2 .

etc. (Numbor of space points

$$
x N_{I} \leq 2(00)
$$

NOTE: A region, $j$, is specified as boing a Dortion of the core (for core power calculation purposes) by entering -EN $j<0$, in which case the number of mesh intervals in region $j$ is taken equal to $E_{j}$.

$2 \quad 17581 \quad R E G_{1}$

$2 \quad 17583 \quad \mathrm{REG}_{2}$

$2 \quad 17585 \quad \mathrm{REG}_{3}$
12 letter $B C D$ giving name of material in region 1 .

Material name for region 2 .

etc.

NOTE: Region material names must, ordinarily, correspond exactly to the material names used in the cross section library. The only exception occurs when the material in a region is mixture of one or more materials in the library. In this case, a distinct name, which will be assigned to the mixture, should be used. If the name of an existing material is used for a mixture, the cross section data for that material will be replaced by the data computed for the mixture. If two or more regions are composed of a mixture, the mixture need only be specified once.

$1 \quad 20245 \quad N 47_{1}=0$

Region one material is already in library (either from data tape, input cards, or a previous mixing).

$$
\mathrm{N}_{1}>0
$$

Material in region one is to be manufactured from a mixture of $\mathrm{N} 47$, materials, the names and proportions of which are specified elsewhere. Material library storage will be set aside, and cleared for a new material. with the name $R E G_{1}$, if none already 
40

$\Sigma($ mixture $)=\sum_{j=j_{1}}^{j=j_{1}+N_{1}-1} \operatorname{voL}(j) * \Sigma(j) \quad N 47>0$

exist. After clearing this area of the library, the mixture cross sections are computed as

where vol( $j)$ is the volume fraction of the $j-t h$ mixture component specified, (which is in the library with name PART ${ }_{1}$ ) $\Sigma$ denotes a typical cross section and $\left(j_{1}-1\right)$ materials have been used in making up mixtures for regions which are closer to the origin than the one for which mixing is presently being performed. $j_{1}=0$ for region 1 , and for region $j$,

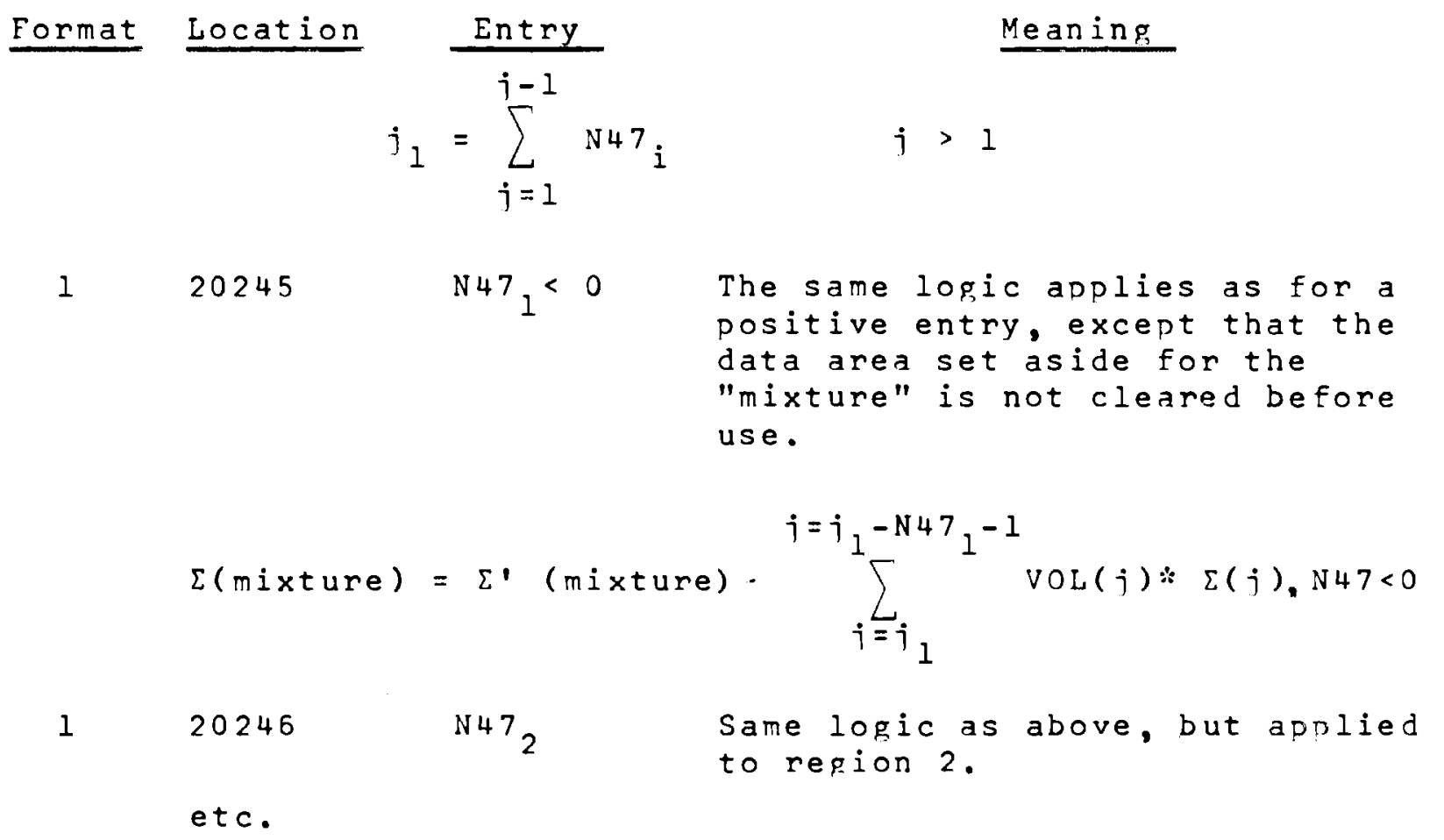

NOTE: $\quad 147$ entries are not set to zeroby the program. In order to save redundant mixing, they should be set to zero, via input, after being used.

$2 \quad 20295 \quad$ PART $_{1}$

12 letter name of material, already specified as part of library, which is first component of first mixture. 


\begin{tabular}{cccc} 
Format & Location & Entry & \multicolumn{1}{c}{ Meaning } \\
2. & 20297 & PART $_{2}$ & Name of second mixture component \\
0 & 20495 & VOL $_{1}$ & $\begin{array}{l}\text { Volume fraction of first mixture } \\
\text { component in first mixture }\end{array}$ \\
0 & 20496 & VOL $_{2}$ & $\begin{array}{l}\text { Volume fraction of second mixture } \\
\text { component }\end{array}$
\end{tabular}

Examples: See HFN Document HW-71545.

11. BOUNDARY CONDITIONS

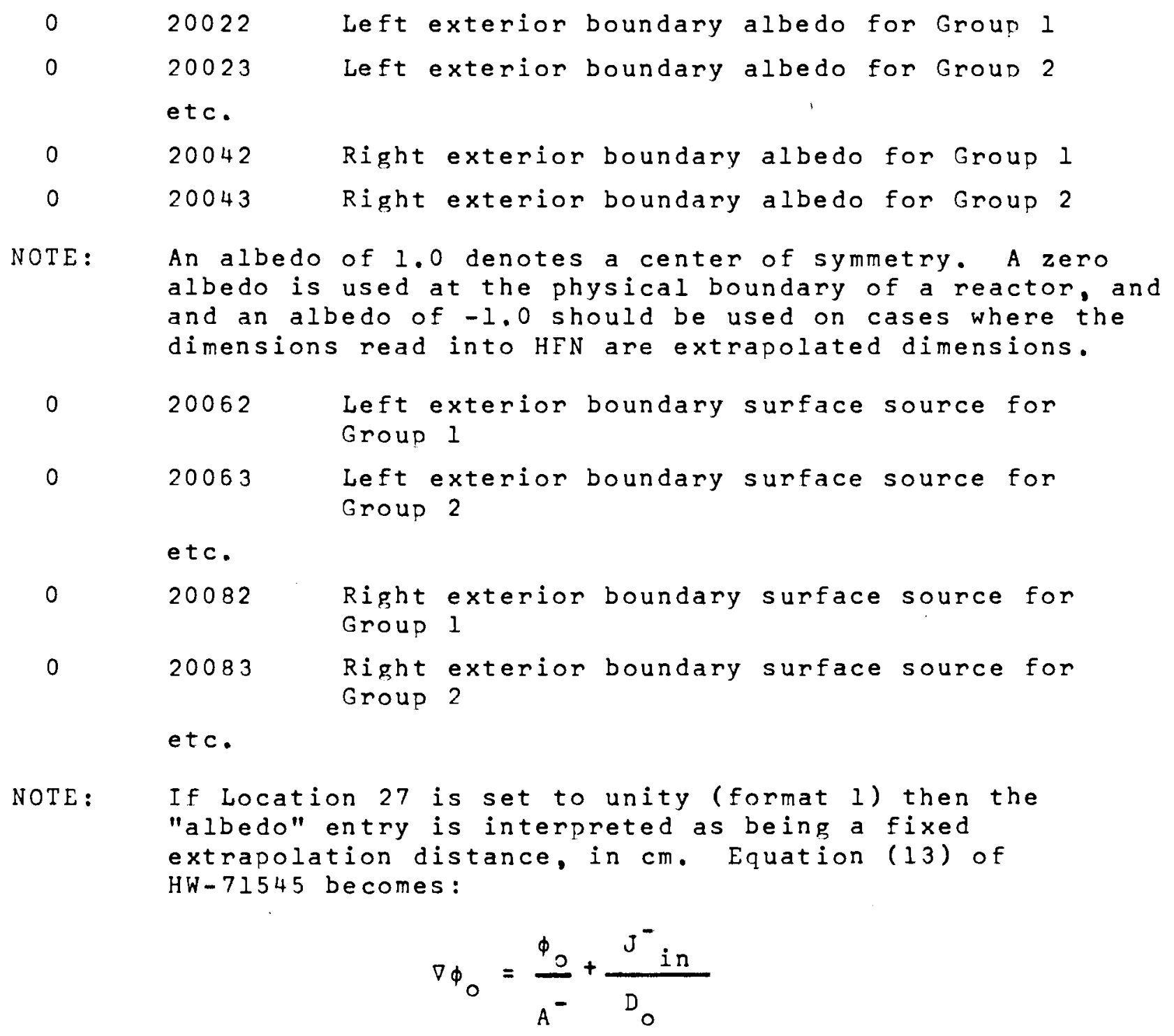


Format Location Entry Meaning

NOTE: If Location 27 is set to - I, then Cohen's formula for the extrapolation distance from a curved surface is used to compute the right exterior boundary (only) condition:

$$
\ell=\frac{A^{+}}{1+1.065669\left(\frac{\mu{ }^{D_{N}}}{R_{N_{R}}}\right)}
$$

where the right "albedo" is the extrapolation distance, in transport mean free paths, from a plane boundary (equals $2 / 3$ according to diffusion theory).

\section{EXTERNAL SOURCE SPECIFICATIONS}

$17882 \quad S_{1}$

External source to right of HFN mesh point Number 1

$17883 \quad S_{2}$

External source to right of HFN mesh point Number 2 .

NOTE: Input to SP array destroyed if $\mathrm{N}_{3}=2$, specifying a regionwise constant source

$\quad 18933 \quad \mathrm{SM}_{2}$

$0 \quad 18934 \quad \mathrm{SM}_{3}$

External source to left of $\mathrm{HFN}$ mesh point Number 2

External source to left of $\mathrm{HFN}$ mesh point Number 3

etc.

NOTE: Input to SM array is destroyed if $N_{3}=1$, specifyino $S M_{i}=S P_{i}$, or if $N_{3}=2$.

020195 SOURCE 1 Strength of spatially constant

$0 \quad 20196 \quad$ SOURCE 2 source in Region 1.

etc.

NOTE: The SOURCE array is ignored unless $\mathrm{N}_{3}=2$. 


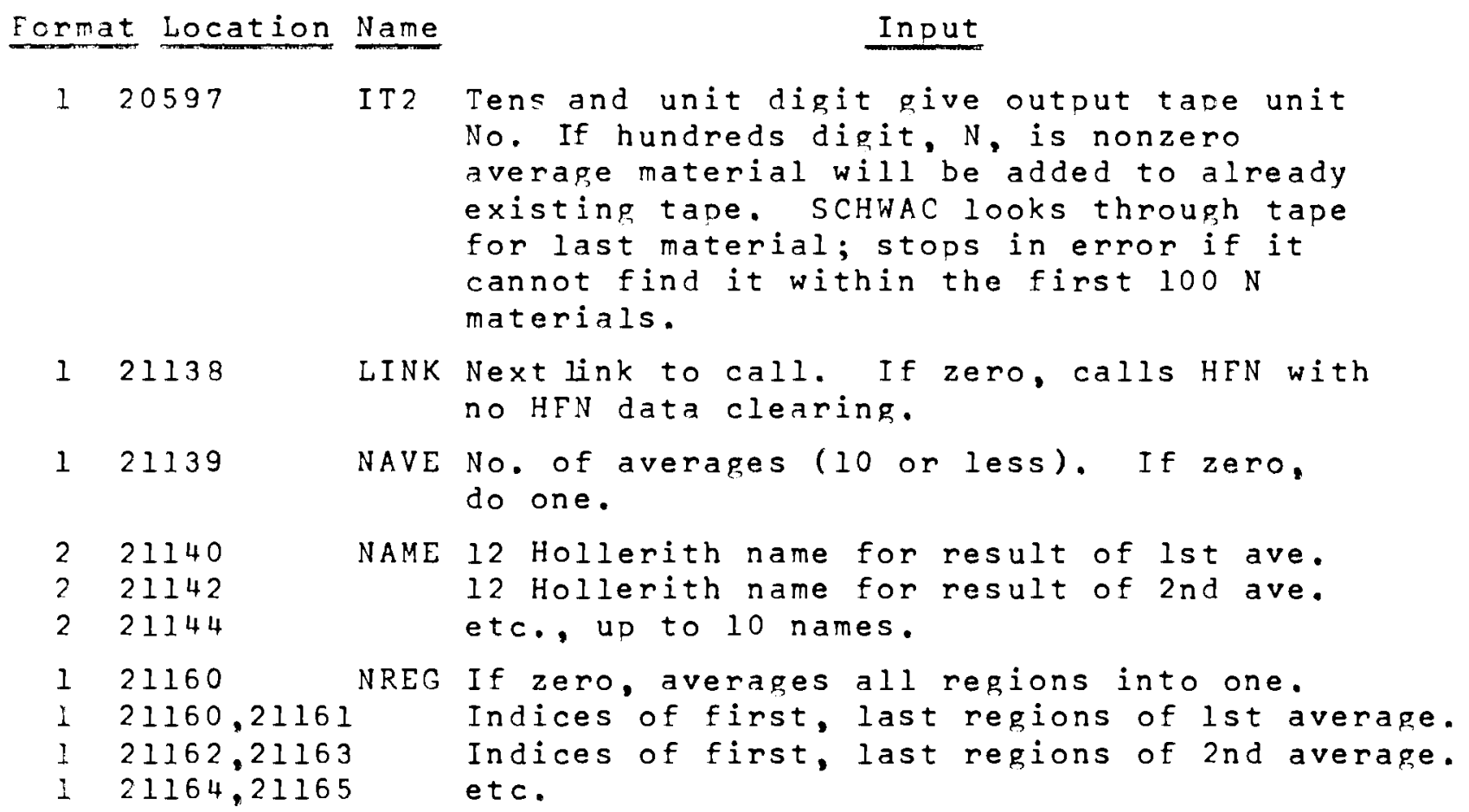

NOTE: SCHWAC does not disturb the data arrays loaded into HFN via LISTIV input, so change cases may be run on HFN after returning from SCHWAC. The above SCHWAC input is unfortunately clobbered so SCHWAC needs a complete new set each case. 


\section{TEMPEST INPUT INSTRUCTIONS}

Card Cols. Format

1

$\begin{array}{rl}1-14 & H \\ 70-72 & I\end{array}$

4

5

$\begin{array}{ll}13-24 & I \\ 25-36 & I \\ 37-48 & I \\ 49-60 & I\end{array}$

7

$\begin{array}{ll}1-3 & I \\ 4-12 & E \\ 13-15 & I \\ 16-24 & E \\ \text { etc. } & \end{array}$

8

BINARY LIBRARY (must be these exact letters.) Logical Tape Unit for Cross Section Library. (If negative expects a CLT).

DATA (must be these exact letters).

Title cards (up to 12) BCD.

X-LAST (must be these exact characters.) Signifies end of title cards.

Temperature (TEMP).

Minimum energy for averaging. (EMIN)

Maximum energy for averaging. (EMAX)

Buckling.

EBRAKE (Leave Blank)

Type of moderation (MTYPE)

1 = heavy approximation

$2=$ light approximation

3 = Maxwellian distribution

I Mode of hydrogen bonding. (MOHB)

201 - free gas

$230=$ water

232 = Butylene

Total number of absorption isotope that determine the spectrum (NISO)

Number of moderators. (NMOD)

Nonzero number to get library listing. ( LIST)

Isotope number used in spectrum determination. (ISO)

Density of above Isotope. (DEN)

Isotope number of second isotope used in spectrum determination.

Corresponding density.

Until all isotopes 1 isted ( 6 per card).

Needed only if nonzero number of moderators and Maxwellian distribution not used.

1-13 I Number of first moderator. (IMOD)

4-12. E Density of first moderator. (DMOD) 


\begin{tabular}{|c|c|c|c|}
\hline Card & Cols. & Format & Input \\
\hline & $\begin{array}{l}13-15 \\
16-24 \\
\text { etc. }\end{array}$ & $\begin{array}{l}I \\
E\end{array}$ & $\begin{array}{l}\text { Number of second moderator. } \\
\text { Density of second moderator. } \\
\text { ( } 6 \text { per card). }\end{array}$ \\
\hline 9 & $13-24$ & I & $\begin{array}{l}\text { Number of isotopes to be averaged (if } \\
\text { negative, will average all isotopes in } \\
\text { library in which case no further cards are } \\
\text { needed. Negative also causes average cross } \\
\text { section to be written B7.) (NAVE) } \\
\text { ITLNK. Link to call after each TEMPEST CASE }\end{array}$ \\
\hline 10 & $\begin{array}{r}1-12 \\
13-24 \\
\text { etc. }\end{array}$ & $\begin{array}{l}I \\
I\end{array}$ & $\begin{array}{l}\text { Number of first isotope to average (NUMA(I) } \\
\text { Number of second isotope to average } \\
(6 \text { per card). }\end{array}$ \\
\hline
\end{tabular}


HRG AND GAM INPUT INSTRUCTIONS

The format for input HRG is described below. The differences between HRG input and GAM-I input as described in GA-1850 are such that GAM-I data can be used by HRG with at most minor modifications. These modifications are: a) the Card 0 formats differ (the card $O$ format is not described in GA-1850 but the data are nevertheless needed) and b) input data for those nuclides requiring resonance integral calculations in $H R G$ but not in GAM-I must also include a card 8 . 


\section{HRG AND GAM INPUT INSTRUCTIONS}

Card

Code

Type Columns Format Mnemoi

Input

Card 0 is needed only in starting a run.

0

1-6 I6 NOID

HRG Library Tape identification number.

Sufficient Cards $1-11$ are needed with each case for a complete specification.

1

$1-72 \quad 12 \mathrm{~A} 6$

$\operatorname{BXCX}(I)$

Case title card.

This information is printed

as heading on each page

of output.

E12

WTP

(MTP)

Type of problem:

$1.0-\mathrm{Pl}$

$2.0-B 1$

3.0 - Fine group fluxes to be read in; fine group currents zeroed internally.

4.0 - Find group fluxes and currents and $P I$ leakage terms to be read in. (HRG only).

5.0 - Fine group fluxes and currents and $B I$ transform parameter to be read in (HRG only).

\section{3-24 E12 WSTU}

(MSTU)

Source:

$$
\begin{aligned}
& 0.0 \text { - Unit source in one } \\
& \text { - fine group. } \\
& 2.0 \text { - U23 fission spectrum. } \\
& 3.0 \text { - U235 fission spectrum. } \\
& 4.0 \text { - Pu239 fission spectrum. } \\
& 5.0 \text { - Cf252 fission spectrum. } \\
& 6.0 \text { - Po-Be (Whitmore-Baker) } \\
& 7.0 \text { - Po-Be (Cochrane-Henry) } \\
& 8.0 \text { - Ra-Be (Hill) }
\end{aligned}
$$


Card Type
Code

Mnemoic

WGHUS

(MGHUS )

STEMP

$37-48$

E12

E12

$$
25-36
$$

E12

$49-60$

E12

$X B C D$

$61-63$
I 3

\section{Input}

Unit source specification: (Needed only if 0.0 in cols. 13-24)

Group number of fine group having the unit source.

System temperature, ${ }^{\circ} \mathrm{K}$ for resonance integral calculation (Used only by GAM).

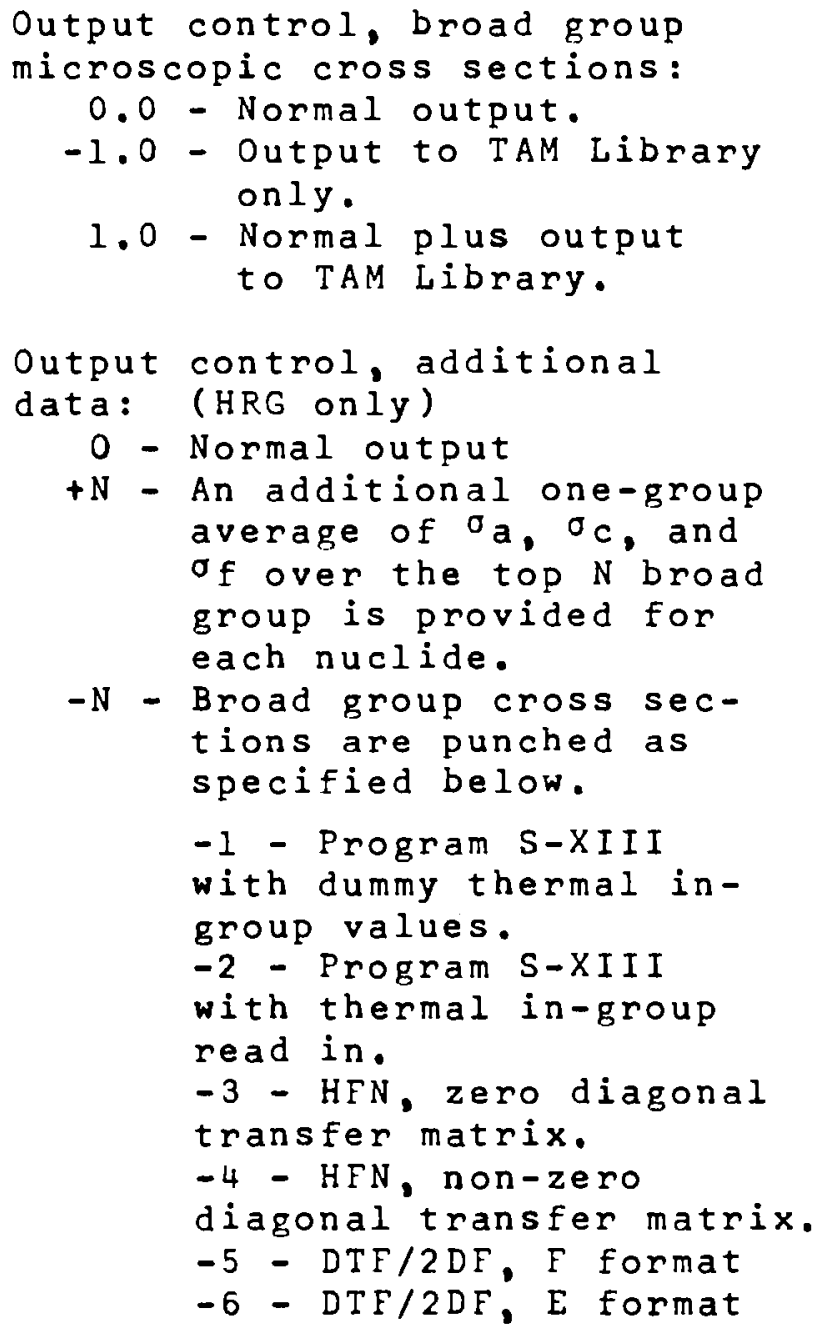




\begin{tabular}{|c|c|c|c|c|}
\hline $\begin{array}{l}\text { Card } \\
\text { Type }\end{array}$ & Columns & Format & $\begin{array}{l}\text { Code } \\
\text { Mnemoic }\end{array}$ & Input \\
\hline & $64-66$ & I 3 & JTO & $\begin{aligned} \text { Output } & \text { control, additional } \\
\text { data: } & \text { (HGR only) } \\
0 \text { - } & \text { Normal output } \\
1- & \text { Fine group fluxes } \\
& \text { written to logical } \\
& \text { unit } 4 \text { at end of the } \\
& \text { case. } \\
-1- & \text { Fine group fluxes } \\
& \text { and currents are } \\
& \text { punched. } 6 \text { per card, } \\
& \text { for future HGR input. }\end{aligned}$ \\
\hline & $67-69$ & I 3 & NTO & $\begin{array}{l}\text { Output control, additional } \\
\text { data: (HGR oniy) } \\
\text { (used only if - } 3 \text { thru }-6 \\
\text { in cols.6l-63) } \\
0 \text { - Punch macroscopic cross } \\
\text { sections for HFN } \\
-1 \text { - Punch nuclide cross } \\
\text { sections for HFN. } \\
N \text { - Number of groups to } \\
\text { which down-scattering } \\
\text { occurs when punching } \\
\text { cross section for DTF/ } \\
\text { 2DF (slo). }\end{array}$ \\
\hline 3 & $1-12$ & E12 & $\begin{array}{l}P O I \\
(\text { NOI })\end{array}$ & Number of nuclides \\
\hline & $13-24$ & E12 & $\begin{array}{l}P N O A G \\
(N O A G)\end{array}$ & Number of broad groups $(\leq 33)$ \\
\hline & $25-36$ & E12 & $\begin{array}{l}\text { PMAGE } \\
(M A G E)\end{array}$ & $\begin{array}{l}\text { Age calculation option: } \\
0.0 \text { - No } \\
1.0 \text { - Yes }\end{array}$ \\
\hline & $37-48$ & E12 & PMICR & $\begin{array}{l}\text { Microscopic cross section to } \\
\text { be averaged over broad groups: } \\
0.0 \text { - No } \\
1.0 \text { - Yes }\end{array}$ \\
\hline & $49-60$ & E12 & $\begin{array}{l}\text { SJGM } \\
(J G M)\end{array}$ & $\begin{array}{l}\text { Geometry specification for } \\
\text { resonance integral calcula- } \\
\text { tion: } \\
0.0 \text { - None } \\
1.0 \text { - Slab } \\
2.0 \text { - Cylinder } \\
3.0 \text { - Sphere }\end{array}$ \\
\hline
\end{tabular}




\begin{tabular}{|c|c|c|c|c|}
\hline $\begin{array}{l}\text { Card } \\
\text { Type }\end{array}$ & Columns & Format & $\begin{array}{l}\text { Code } \\
\text { Mnemonic }\end{array}$ & Input \\
\hline 4 & $1-72$ & $6 \mathrm{E} 12$ & $C E G(I)$ & $\begin{array}{l}\text { Broad group energy boundaries: } \\
\text { Lower energy boundary, in } \\
\text { electron volts and in decreas } \\
\text { ing magnitude, } 6 \text { values per } \\
\text { card for as many broad } \\
\text { groups as given by PNOAG, } \\
\text { Cols. } 13-24 \text { of Card } 3 \text {. }\end{array}$ \\
\hline $5 \mathrm{~A}$ & $1-72$ & $6 \mathrm{E} 12$ & $A J(I)$ & $\begin{array}{l}\text { Fine group currents: (HRG } \\
\text { only) } \\
\text { (Needed only if } 4.0 \text { or } 5.0 \\
\text { in cols. } 1-12 \text { of Card } 2 \text { ). } \\
\text { Fine group currents to be } \\
\text { read in, } 6 \text { per card, } 68 \text { total }\end{array}$ \\
\hline $5 \mathrm{~B}$ & $1-72$ & $6 \mathrm{E} 12$ & APHI (I) & $\begin{array}{l}\text { Fine group fluxes: } \\
\text { (Needed only if } 3.04 .0, \\
\text { or } 5.0 \text { in cols. } 1-12 \text { of } \\
\text { Card } 2 \text { ). Fine group fluxes } \\
\text { to be read in, } 6 \text { per card, } \\
68 \text { total. }\end{array}$ \\
\hline \multirow{4}{*}{6} & \multicolumn{2}{|c|}{$\begin{array}{l}\text { Nuclide Data } \\
\text { in order, as } \\
\text { be arranged i } \\
\text { numbers. }\end{array}$} & $\begin{array}{l}\text { Cards. A se } \\
\text { needed, for } \\
\text { n ascending }\end{array}$ & $\begin{array}{l}\text { t of cards } 6-8 \text { must be supplied } \\
\text { each nuclide; the sets must } \\
\text { order of nuclide identification }\end{array}$ \\
\hline & $1-12$ & E12 & $\begin{array}{l}\text { PMANU } \\
(\text { MANU) }\end{array}$ & $\begin{array}{l}\text { Nuclide identification number } \\
\text { (see attached list) }\end{array}$ \\
\hline & $13-24$ & E12 & $A D E N$ & $\begin{array}{l}\text { Nuclide density per barn-cm. } \\
\text { A negative value indicates } \\
\text { nuclide cross sections } \\
\text { should be converted to } \\
\text { macroscopic form (multiplied } \\
\text { by |ADEN|) before being } \\
\text { written and punched as out- } \\
\text { put. }\end{array}$ \\
\hline & $25-36$ & E12 & SSON & $\begin{array}{l}\text { Self-shielding factor input } \\
\text { specification: } \\
0.0 \text { - No } \\
1.0 \text { - Yes }\end{array}$ \\
\hline
\end{tabular}




\begin{tabular}{|c|c|c|c|c|}
\hline $\begin{array}{l}\text { Card } \\
\text { Type } \\
\end{array}$ & Columns & Format & $\begin{array}{l}\text { Code } \\
\text { Mnemonic } \\
\end{array}$ & Input \\
\hline \multicolumn{5}{|r|}{ 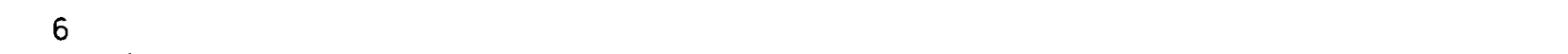 } \\
\hline$(\operatorname{con} t)$ & $37-48$ & E12 & HATSS & $\begin{array}{l}\text { Self-shielding factor type } \\
\text { specification: } \\
\text { (Needed only if } 1.0 \text { in } \\
\text { cols. } 25-36 \text { ) } \\
0.0 \text { - Broad group } \\
1.0 \text { - Fine group }\end{array}$ \\
\hline 7 & $1-72$ & $6 \mathrm{E} 12$ & $\operatorname{PSFS}(I)$ & $\begin{array}{l}\text { Self-shielding factors: } \\
\text { (Needed only if } 1.0 \text { in } \\
\text { cols. } 25-36 \text { of card } 6 \text { ). } \\
\text { Self-shielding factors to } \\
\text { be read in, } 6 \text { per card, for } \\
\text { a total of: } \\
\text { PNOAG values (cols. } 13-24 \\
\text { in Card } 3 \text { ) if } 0.0 \text { in cols. } \\
37-48 \text { in Card } 6 ; 68 \text { val- } \\
\text { ues if } 1.0 \text { in cols. } 37-48 \\
\text { in Card } 6 .\end{array}$ \\
\hline \multirow[t]{4}{*}{8} & & & & $\begin{array}{l}\text { Resonance integral calcula- } \\
\text { tion data: } \\
\text { (Needed only if nuclide } \\
\text { requires a resonance inte- } \\
\text { gral calculation. Such } \\
\text { nuclides are indicated by } \\
\text { an asterisk in the list } \\
\text { of identification numbers) }\end{array}$ \\
\hline & $1-12$ & E12 & $\operatorname{SIG}(1,1)$ & $\begin{array}{l}\text { 'm admixed moderator scat- } \\
\text { téring cross section per } \\
\text { atom of this nuclide ( } \sigma \text { = } \\
0.0 \text { for pure metal), used in } \\
\text { IM approximation. }\end{array}$ \\
\hline & $13-24$ & E12 & $\operatorname{SIG}(2,1)$ & $\begin{array}{l}\sigma_{\text {sital total of }} \text { sesonce } \\
\text { seattering cross section per } \\
\text { atom of this nuclide ( } \sigma_{p}= \\
\sigma_{m}=\sigma_{\text {potential }} \text {, used in } \\
\text { NR approximation. }\end{array}$ \\
\hline & $25-36$ & E12 & SIGU ( I ) & $\begin{array}{l}\sigma_{m} \text { eff, effective total } \\
\text { off-resonance scattering } \\
\text { cross section per absorber } \\
\text { atom of this nuclide, based } \\
\text { on wigner's rational approx- } \\
\text { imation, used in unresolved } \\
\text { resonance calculation. }\end{array}$ \\
\hline
\end{tabular}




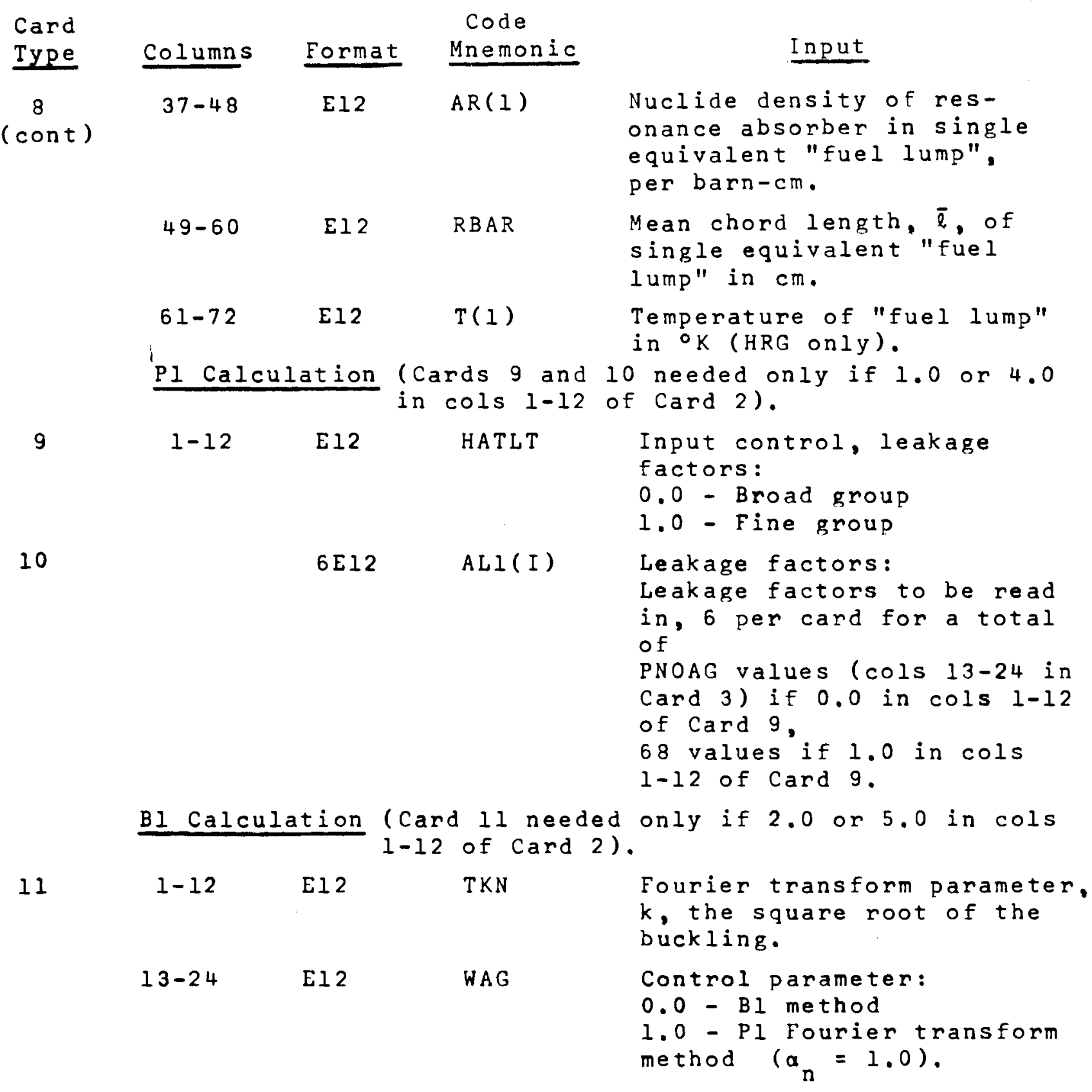




\begin{tabular}{|c|c|c|c|c|}
\hline $\begin{array}{l}\text { Card } \\
\text { Type }\end{array}$ & Columns & Format & $\begin{array}{l}\text { Code } \\
\text { Mnemonic }\end{array}$ & Input \\
\hline \multirow[t]{5}{*}{12} & & & & $\begin{array}{l}\text { Thermal cross sections for } \\
\text { punch option: (HRG only). } \\
\text { This cardis necessary only } \\
\text { if cols } 61-63 \text { of Card Type } 2 \\
\text { (ITO) contain }-2 \text {. One card } \\
\text { of this type is then required } \\
\text { for each nuclide in this case } \\
\text { (the number in cols l-l2 of } \\
\text { Card Type } 3 \text { ). These cards } \\
\text { appear directly behind the } \\
\text { regular HRG input for this } \\
\text { case. }\end{array}$ \\
\hline & $1-5$ & I 5 & I so & $\begin{array}{l}\text { HRG nuclide identification } \\
\text { number. }\end{array}$ \\
\hline & $6-63$ & $4 E 14$ & SNSG(I) & $\begin{array}{l}\text { Thermal group cross sections } \\
\text { for this nuclide as follows: }\end{array}$ \\
\hline & & & & $v \sigma_{f} \quad P O(t h-t h)$ \\
\hline & & & & $\sigma_{\text {tot }} \quad P I(t h-t h)$ \\
\hline \multirow[t]{2}{*}{13} & $1-3$ & I 3 & ILINK & $\begin{array}{l}\text { Link number to call next. } \\
\text { If this entry is negative } \\
\text { the TAM Library will not be } \\
\text { rewound. }\end{array}$ \\
\hline & $4-6$ & I 3 & ITAPE & (Not used on 1107 Runs) \\
\hline NOTE: & $\begin{array}{l}\text { If makir } \\
\text { should }\end{array}$ & $\begin{array}{l}\text { a TYPE } \\
\text { onitted }\end{array}$ & run (PSPI & card 13 is not used and \\
\hline
\end{tabular}


SIGMA-3C INPUT INSTRUCTIONS

\begin{tabular}{|c|c|c|}
\hline Format & Location & Name \\
\hline 2 & 1 & $K B C D$ \\
\hline 1 & 14 & NGROUP \\
\hline 1 & 15 & NTHERM \\
\hline 1 & 16 & ISO \\
\hline 1 & 17 & IMIX \\
\hline 1 & 18 & NMIX \\
\hline 1 & 19 & LINK \\
\hline 1 & 20 & ITAPE \\
\hline 1 & 21 & JXE \\
\hline 1 & 24 & KBND \\
\hline 1 & 25 & KGO \\
\hline 1 & 26 & $\mathrm{NFP}_{1}$ \\
\hline
\end{tabular}

Input

72 character Hollerith headings will be used for CALX data tape identification.

Total number of groups ( $=9$ for $(A L X)$

Number of thermal groups $(=1$ for $(A L X)$

Number of non-fuel burnable isotopes treated separately from gross fission products in burnup analysis; maximum 100

Number of mixtures. These mixtures become the base materials in CALX and neither burn nor contain fuels. Presently either 1 or 2 for CALX.

Number of mixture components; maximum 200

$>$ o Chain link number to call next

$=0$ Rewind TAM tape, start another case.

< o Start another case analyzing next TAM case.

$=0$ Calls exit when through

$>0$ Chain tape number on which next link is located ( 3 for CALX system)

Set to unity to keep $\mathrm{Xe}-135, \mathrm{Sm}-149$, and $I-135$ at current equilibrium value during course of burnup.

Boundary conditions in CALX

$=0$ for cell

$=1$ for symmetric half reactors

$=2$ for homogeneous single region

Geometry control for CALX

$=0$ for slab

$=1$ for cylinder

$=2$ for sphere (currently unavailable)

Set to unity to mix a gross fission product from table number 1 . 


\begin{tabular}{|c|c|c|c|}
\hline Format & Location & Name & Input \\
\hline 1 & 27 & $\mathrm{NFP}_{2}$ & Unity to mix GFP from Table 2 \\
\hline 1 & 28 & $\mathrm{NFP}_{3}$ & Unity to mix GFP from Table 3 \\
\hline 1 & 29 & $\mathrm{NFP}_{4}$ & Unity to mix GFP from Table 4 \\
\hline 1 & 30 & $\mathrm{NFP}_{5}$ & Unity to $\mathrm{mix}$ GFP from Table 5 \\
\hline 1 & 32 & $\mathrm{KDUMP}_{2}$ & $\begin{array}{l}\text { Non-zero to dump thermal absorption } \\
\text { cross section and TEMPEST data from } \\
\text { which computed. }\end{array}$ \\
\hline 1 & 33 & $\mathrm{KDUMP}_{3}$ & $\begin{array}{l}\text { Non-zero to dump thermal fission } \\
\text { information }\end{array}$ \\
\hline 1 & 34 & KDUMP $_{4}$ & $\begin{array}{l}\text { Non-zero to dump thermal transport } \\
\text { information }\end{array}$ \\
\hline 1 & 35 & $\mathrm{KDUMP}_{5}$ & $\begin{array}{l}\text { Non-zero to dump thermal scatter } \\
\text { information }\end{array}$ \\
\hline 1 & 36 & KDUMP $_{6}$ & $\begin{array}{l}\text { Non-zero to dump fuel accounting } \\
\text { data }\end{array}$ \\
\hline 1 & 37 & KDUMP $_{7}$ & $\begin{array}{l}\text { Dump NGROUP cross sections and GAM } \\
\text { and TEMPEST isotope numbers for } \\
\text { first KDUMP SIGMA-3 isotopes. } \\
\text { If negative dump information only } \\
\text { for SIGMA-3 isotope KDUMP } 7^{\circ}\end{array}$ \\
\hline 1 & 38 & $\mathrm{KDUMP}_{8}$ & $\begin{array}{l}\text { Non-zero to dump fission product } \\
\text { yields, mixture components, and } \\
\text { fractions }\end{array}$ \\
\hline 1 & $41-200$ & JBURN & $\begin{array}{l}\text { The fuel isotopes of interest are } \\
\text { specified in this array. See } \\
\text { Table } 3 \text {, Appendix I, for input } \\
\text { locations for each isotope with } \\
\text { reference to its particular owner. }\end{array}$ \\
\hline 1 & $201-300$ & NISO & $\begin{array}{l}\text { SIGMA- } 3 \text { numbers of the non-fuel } \\
\text { isotopes of interest }\end{array}$ \\
\hline & 201 & $\mathrm{NISO}_{1}$ & $\begin{array}{l}\text { SIGMA-3 number of first non-fuel } \\
\text { isotope }\end{array}$ \\
\hline & 202 & $\mathrm{NISO}_{2}$ & SIGMA-3 number of second \\
\hline & 203 & $\mathrm{NISO}_{3}$ & Etc., for all non-fuel isotopes \\
\hline
\end{tabular}




\begin{tabular}{|c|c|c|}
\hline Format & Location & Name \\
\hline \multirow[t]{4}{*}{1} & $301-500$ & MIX \\
\hline & 301 & $\operatorname{MIX}_{1}$ \\
\hline & 302 & $\operatorname{MIX}_{2}$ \\
\hline & 303 & $\operatorname{MIX}_{3}$ \\
\hline 1 & 591 & MISC $_{9 I}$ \\
\hline 1 & 592 & MISC $_{92}$ \\
\hline 1 & 593 & MISC $_{93}$ \\
\hline 1 & 594 & MISC $_{94}$ \\
\hline 1 & 595 & MISC $_{95}$ \\
\hline 1 & 596 & MISC $_{96}$ \\
\hline 1 & 597 & MISC $_{97}$ \\
\hline 2 & $601-640$ & KALL \\
\hline
\end{tabular}
Input
SIGMA-3 isotope numbers of mixture
components

SIGMA-3 number of first-mixture is otope

SIGMA-3 number of second

Etc., for all mixture components

A non-zero entry here will suppress writing of logical record number 1 on the CALX data tape

(Suggested entry: None.)

Non-zero will suppress writing of logical Record 2

Non-zero will suppress logical Record 3

Non-zero will suppress logical Record 4

Non-zero will suppress logical Record 5

Non-zero will suppress logical Record 6

Non-zero to suppress logical

Record 7. (If not type III problem, enter a 1 here)

Name of SIGMA-3 fuel isotope. A name must be entered for each fuel isotope used in the problem. To find the proper location for this name in the KALL array, add the isotope's SIGMA-3 number to 600 .

Example: If $U-235$ and $U-238$ are used, enter bu-235 in location 620 and bU-238 in location 623. (b Indicates blank)

0

641

HE I GH T

Reactor or cell "height" When multiplied by thickness or radius gives volume for slab and spherical geometry, and gives cross section area for cylindrical geometry.

$0 \quad 643 \quad$ DXE

Starting guess at equilibrium Xe-135 density if location 21 is unity 


\begin{tabular}{|c|c|c|c|}
\hline Format & Location & Name & Input \\
\hline 0 & 645 & DI & I-135 equilibrium density guess \\
\hline 0 & 646 & $\operatorname{DENFP}_{1}$ & Initial concentration of $G_{1}$ \\
\hline 0 & 647 & $\mathrm{DENFP}_{2}$ & Initial concentration of $\mathrm{GFP}_{2}$ \\
\hline 0 & 648 & $\mathrm{DENFP}_{3}$ & Initial concentration of $\mathrm{GFP}_{3}$ \\
\hline 0 & 649 & $\operatorname{DENFP}_{4}$ & Initial concentration of $\mathrm{GFP}_{4}$ \\
\hline 0 & 650 & $\mathrm{DENFP}_{5}$ & Initial concentration of $\mathrm{GFP}_{5}$ \\
\hline 0 & 651 & $\mathrm{R}_{1}$ & Outer radius of first region $(\mathrm{cm})$ \\
\hline 0 & 652 & $\mathrm{R}_{2}$ & Outer radius of second region $(\mathrm{cm})$ \\
\hline 0 & $661-669$ & BSQ & $\begin{array}{l}\text { Perpendicular buckling for each } \\
\text { group to get effect of finite } \\
\text { size on neutron spectrum } \\
\text { (Enter a B } 2 \text { value for each of } 9 \\
\text { groups in successive locations) }\end{array}$ \\
\hline 0 & $741-900$ & DBURN & $\begin{array}{l}\text { Initial concentrations for fuel } \\
\text { isotopes as entered in the JBURN } \\
\text { array for the fuel isotope being } \\
\text { used. See Table 3, Appendix I. }\end{array}$ \\
\hline & & & $\begin{array}{l}\text { Example: } 4.0 \times 10^{-4} \text { entered in } \\
\text { location } 830 \text { would be the con- } \\
\text { centration of that portion of } \\
\text { U- } 238 \text { that belonged to owner two. }\end{array}$ \\
\hline 0 & $901-1000$ & DENS & $\begin{array}{l}\text { Initial densities of the individual } \\
\text { non-fuel isotopes }\end{array}$ \\
\hline & 901 & & $\begin{array}{l}\text { Initial density of first non-fuel } \\
\text { isotopes }\end{array}$ \\
\hline & 902 & & $\begin{array}{l}\text { Initial density of second non-fuel } \\
\text { isotopes }\end{array}$ \\
\hline & 903 & & $\begin{array}{l}\text { Etc. for number of specified } \\
\text { non-fuels }\end{array}$ \\
\hline 0 & $1001-1200$ & FRAC $_{I, 1}$ & $\begin{array}{l}\text { Concentrations of each MIX in the } \\
\text { first mixture (Base for region } \\
\text { Number l) }\end{array}$ \\
\hline 0 & 1001 & $\mathrm{FRAC}_{1,1}$ & $\begin{array}{l}\text { Concentrations of first mixture } \\
\text { component (MIX,) in first mixture }\end{array}$ \\
\hline
\end{tabular}


Format Location Name

$1002 \quad$ FRAC $_{2,1}$

$1003 \quad \mathrm{FRAC}_{3,1}$

0

$\begin{array}{cc}1201-1400 & \text { FRAC }_{1,2} \\ 1201 & \text { FRAC }_{1,2} \\ 1202 & \text { FRAC }_{2,2} \\ 1203 & \text { FRAC }_{3,2}\end{array}$

Input

Concentrations of second component of first mixture

Etc., for all components of mixture one

Concentrations of each MIX in the second mixture (Base for Region 2)

Concentrations of first component in second mixture

Concentrations of second component in second mixture

Etc., for all components of the second mixture 


\begin{tabular}{|c|c|c|c|}
\hline \multirow[b]{3}{*}{ Format } & \multirow[b]{3}{*}{ Location } & \multicolumn{2}{|c|}{ INPUT INSTRUCTIONS FOR CALX } \\
\hline & & 1. CONTROL & INPUT FOR CALX \\
\hline & & $\begin{array}{l}\text { Array } \\
\text { Size Name }\end{array}$ & Comments \\
\hline 1 & 16 & ITAPE ( 1$)$ & $\begin{array}{l}\text { This is the control for the binary } \\
\text { input tape made uP from SIGMA-3C } \\
\text { (CALX data tape). } \\
\text { 1-DO NOT READ TAPE } \\
\text { O-READ TAPE } \\
\text { - l-REWIND AND READ } \\
\text { (automatically set to unity after } \\
\text { tape is read.) }\end{array}$ \\
\hline 1 & 5942 & KM & OUTPUT TAPE NUMBER \\
\hline 1 & 5943 & $\mathrm{Nl}$ & Link number to call next. \\
\hline 1 & 5944 & JNP & $\begin{array}{l}\text { Number of lines of extra heading to } \\
\text { be copied to output tape. (Set to } \\
\text { zero after reading.) JNP cards of } \\
\text { Hollerith information follow tape } \\
\text { specification cards. }\end{array}$ \\
\hline 1 & 5948 & NUMBER & CALX case number. Updated by Program. \\
\hline 1 & 5949 & N6 & $\begin{array}{l}\text { Case control } \\
\text { 1-NOT LAST CASE (automatically set } \\
\text { to } 1 \text { for first case.) } \\
\text { 0-LAST CASE-CALLS EXIT } \\
\text { - I-CALLS NEXT CHAIN LINK } \\
\text { (if N6 =-1 link\# is needed in NI) }\end{array}$ \\
\hline 1 & 5953 & I T I ME & $\begin{array}{l}\text { Set non-zero to run internal } \\
\text { timing routine. }\end{array}$ \\
\hline 1 & 5962 & N 5 & $\begin{array}{l}=1 \text { for constant power burnup } \\
=2 \text { for constant fluc burnup }\end{array}$ \\
\hline 0 & 5963 & PWI** & $\begin{array}{l}\text { Value of the constant power density } \\
\text { in watts per unit volume or the } \\
\text { constant flux in } n / b a r n-c m \text {. } \\
\text { (Exception: If XK }=0 \text { when } 5=1 \text {, } \\
\text { PWI units are megawatts/metric ton.) }\end{array}$ \\
\hline 0 & 5988 & TMAX & Time limit on exposure run, in seconds. \\
\hline 0 & 5989 & BMULT** & Limit on irradiation \\
\hline 0 & 5990 & EAE & $\begin{array}{l}\text { Allowed differences between BMULT and } \\
\text { end point if NS6 }=2 \text {. }\end{array}$ \\
\hline 0 & 5965 & DENS** & Core fuel density, $g \mathrm{~m} / \mathrm{cc}$. \\
\hline
\end{tabular}




\begin{tabular}{|c|c|c|c|c|}
\hline Format & Location & $\begin{array}{l}\text { Array } \\
\text { Size }\end{array}$ & Name & Comments \\
\hline 1 & 8863 & & NPUT 2 & $\begin{array}{l}\text { Non-zero if more input is to be } \\
\text { read in after data tape has been } \\
\text { read. (This is for changing input } \\
\text { from tape.) Automatically set to } \\
\text { zero after second input. }\end{array}$ \\
\hline 1 & 8864 & & NWR I T & $\begin{array}{l}=1-\text { input } 9 \text { group cross sections } \\
\text { will be written out (automatically } \\
\text { set to zero after writing). } \\
=0-i n p u t 9 \text { group cross sections } \\
\text { will not be written out. }\end{array}$ \\
\hline 0 & 5099 & 90 & SHIELD & $\begin{array}{l}\text { Constant linear, quadratic shield } \\
\text { factor ( } 3 \text { per fuel)(presently } \\
\text { unused). }\end{array}$ \\
\hline 0 & 5189 & 300 & SHIELD & Self-shielding factor ( $3 /$ non-fuel). \\
\hline 1 & 5489 & 30 & INREG & $\begin{array}{l}\text { Fuel region number (currently all } \\
\text { fuels must be in Region l). If not } \\
\text { input, CALX puts all fuels in } \\
\text { Region l. }\end{array}$ \\
\hline 0 & 6023 & & $A K R A C Y * *$ & $(k) \quad(k-1)$ \\
\hline & & & & $\frac{\phi_{i}-\phi_{i}}{\phi_{i}^{k}} \leq$ AKRACY for convergence \\
\hline & & & & $\begin{array}{l}\text { on } k^{t h} \text { iteration of spectrum } \\
\text { calculation. If zero, uses } 0.0001 \text {. }\end{array}$ \\
\hline 1 & 6024 & & NITER ** & $\begin{array}{l}\text { Maximum number of iterations in } \\
\text { spectrum calculation. If zero, } \\
\text { uses } 50 \text {. }\end{array}$ \\
\hline 1 & 6025 & & NMI ** & $\begin{array}{l}\text { Number of mesh intervals in } \\
\text { Region } 1 \text {. If zero, uses } 24 \text {. }\end{array}$ \\
\hline 1 & 6026 & & NM2** & $\begin{array}{l}\text { Number of mesh intervals in } \\
\text { Region } 2 \text {. If zero, uses } 23 \text {. }\end{array}$ \\
\hline 1 & 6027 & & IC $4 * *$ & $\begin{aligned} \text { if } & =0 \text { uses equal mesh spacing } \\
& \neq 0 \text { uses equal volume spacing }\end{aligned}$ \\
\hline 0 & 12313 & & TYME** & Starting time for burnup. \\
\hline 1 & 5519 & 100 & INREG & $\begin{array}{l}\text { Non-fuel region number (currently } \\
\text { all non-fuels must be in Region } 1 \text { ). } \\
\text { If not input CALX puts all non- } \\
\text { fuels in Region } 1 \text {. }\end{array}$ \\
\hline
\end{tabular}




\begin{tabular}{|c|c|c|c|c|}
\hline Format & Location & $\begin{array}{l}\text { Array } \\
\text { Size }\end{array}$ & Name & Comments \\
\hline 1 & 5649 & 30 & IREC & $\begin{array}{l}\text { Fuel recycle product number. If } \\
\text { not input fuels recycle into same } \\
\text { isotope. Used to change owners of } \\
\text { fuels during downtime. }\end{array}$ \\
\hline 1 & 12311 & & IFMWNT & $\begin{array}{l}\text { Number of tapes to mount. IFMWNT } \\
\text { tape specification cards follow } \\
\text { first } 9 \text { card (automatically set to } \\
\text { zero after mounting tapes). }\end{array}$ \\
\hline 1 & 5975 & & N17 & 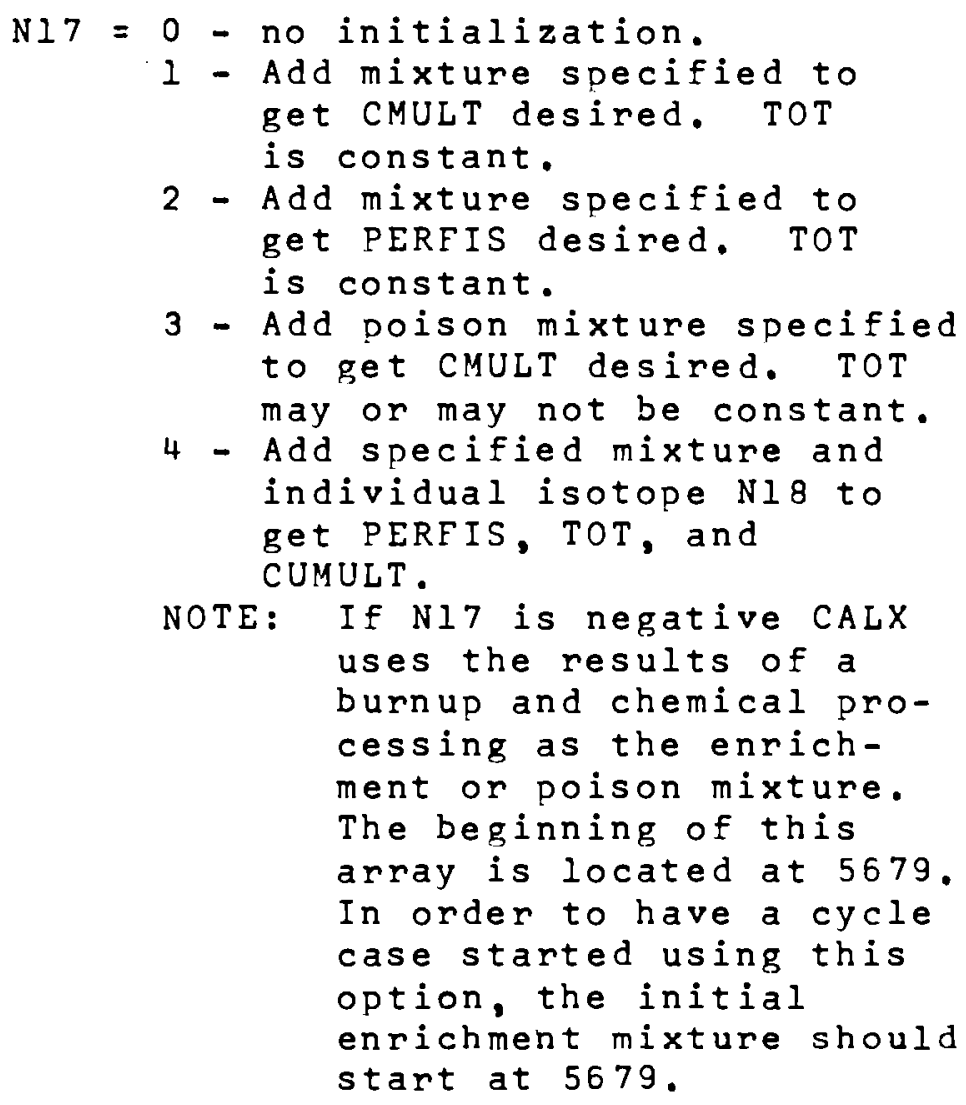 \\
\hline 1 & 5976 & & $\mathrm{~N} 18$ & $\begin{array}{l}\text { Accounting number of individual } \\
\text { isotope to use when } N 17=4 \text {. }\end{array}$ \\
\hline 1 & 5977 & & N19 & $\begin{array}{l}\text { Maximum number of initialization } \\
\text { iterations. }\end{array}$ \\
\hline 1 & 5979 & & CMULT & Initial XMULT desired. \\
\hline 0 & 5980 & & CMATCH & Accuracy required in CMULT. \\
\hline 0 & 5981 & & TOT & $\begin{array}{l}\text { Total fuel density. If this entry is } \\
\text { not specified the program will use the } \\
\text { TOT of the input concentrations. }\end{array}$ \\
\hline
\end{tabular}




\begin{tabular}{|c|c|c|c|c|}
\hline Format & Location & $\begin{array}{l}\text { Array } \\
\text { Size }\end{array}$ & Name & Comments \\
\hline 0 & 5982 & & PERFIS & Fissile atom fraction \\
\hline \multirow[t]{2}{*}{0} & 5809 & 130 & YAA & $\begin{array}{l}\text { Enrichment or poison composition. } \\
\text { Concentration of accounting isotope } \\
\text { one goes in } 5809 \text {, etc. }\end{array}$ \\
\hline & & 3. & IPUT FOR & RECYCLE CASE \\
\hline 0 & 6008 & & DEL & Days of AEC charge period and startur \\
\hline 0 & 6009 & & DDAYS I & Days from discharge to processing \\
\hline 0 & 6010 & & DDAYS & $\begin{array}{l}\text { Days from fabrication to fabrication- } \\
\text { recharge; use only on graded cycle. }\end{array}$ \\
\hline 1 & 6013 & & NPASS & Maximum number of recycle passes \\
\hline 0 & 156 & 30 & PERSAV & $\begin{array}{l}\text { Recovery efficiency of fuel chemical } \\
\text { reprocessing. If negative adds fuel } \\
\text { (initial concentrations) to recycle } \\
\text { mix. }\end{array}$ \\
\hline 0 & 186 & 100 & PERSAV & $\begin{array}{l}\text { Recovery efficiency of non-fuel } \\
\text { chemical reporcessing. If negative } \\
\text { adds fuel (initial concentrations) } \\
\text { to recycle mix. }\end{array}$ \\
\hline 0 & 6012 & & DEXP & $\begin{array}{l}\text { Maximum fractional difference in } \\
\text { exposure, for two successive passes, } \\
\text { for equilibrium. Recycle will stop } \\
\text { when this limit is reached. }\end{array}$ \\
\hline & & 4. & IPUT FOR & GRADED CASE ONLY \\
\hline
\end{tabular}

To run a graded case a constant power burnup must be set up with the following additions:

$0 \quad 6011$

1

6017
N5 7

RMATCH
Maximum positive fractional case difference. Non-zero number here starts graded run.

Maximum number of graded cycles per fuel lifetime.

5. INPUT FOR ECONOMICS CASE

$16014 \quad$ N2

16018

16019

$1 \quad 6021$
I DEN T

NSTEP

PERIOD
Tape unit number for economics output, Economics case number

Non-zero positive to get economics output.

Time between economics output, days. 
CALX INPUT - READ IN FROM CALX DATA TAPE

Array

\begin{tabular}{crrll} 
Format & Location & $\frac{\text { Size }}{2}$ & \multicolumn{1}{c}{ Name } \\
1 & 13 & 12 & BCD \\
0 & 14 & 2 & RADIUS \\
1 & 16 & 10 & ITAPE \\
& & & \\
0 & 26 & 30 & C \\
0 & 56 & 100 & C \\
0 & 286 & 9 & BSQ \\
0 & 295 & 9 & EDGE
\end{tabular}

$\begin{array}{llll}0 & 304 & 30 & \text { KPHYS } \\ 1 & 334 & 30 & \text { NPFYT }\end{array}$

$\begin{array}{rrrl}1 & 364 & 15 & \text { NRFYT } \\ 0 & 379 & 9 & \text { FIS } \\ 0 & 388 & 15 & Q \\ 1 & 403 & 30 & \text { KCP } \\ 1 & 433 & 30 & \text { KDP } \\ 1 & 463 & 100 & \text { KDP } \\ 0 & 563 & 30 & \text { GLAM }\end{array}$
Comments
Case identification - 72 characters.
Current page number
Region radii
Binary tape control
0 - TO READ
+1 - TO NOT READ

Fuel isotopic concentrations

Non-fuel isotopic concentrations

System geometric buckling

Fluxes at edge of cell (for continuous irradiation)

Physical fuel isotope numbers

Accounting fuel fission product $y$ ield table number

Actual fuel fission product yield table number

Fraction of $f$ ission neutrons born into group

Energy per fission, joules

Fuel capture product index

Fuel decay product index

Non-fuel decay product index

Fuel radioactive decay constants, $\sec ^{-1}$

Non-fuel radioactive decay constants, $\sec ^{-1}$

Capture transmutation fraction

( 2 /non-fuel)

Fission product yield table number 1

Fission product yield table number 2

Fission product yield table number 3

Fission product yield table number 4

Fission product yield table number 5 


\begin{tabular}{|c|c|c|c|c|}
\hline Format & Location & $\begin{array}{l}\text { Array } \\
\text { Size }\end{array}$ & Name & Comments \\
\hline 0 & 1393 & 135 & SIGNUL & Fuel $v \alpha_{f}(9 /$ physical fuel) \\
\hline 0 & 1528 & 135 & S IGFL & Fuel $\sigma_{f}(9 /$ physical fuel) \\
\hline 0 & 1663 & 135 & S I GRL & Fuel $\sigma_{r}(9 /$ physical fuel $)$ \\
\hline 0 & 1798 & 900 & S I GR L & Non-fuel $\sigma_{r}$ \\
\hline 0 & 2698 & 120 & SIGSDL & Fuel $\sigma_{j \rightarrow j+1}$ (8/physical fuel) \\
\hline 0. & 2818 & 800 & SIGSDL & Non-fuel $\sigma_{j \rightarrow j+1}$ \\
\hline 0 & 3618 & 135 & SIGTRL & Fuel $\sigma_{\text {tr }}(9 /$ physical fuel) \\
\hline 0 & 3753 & 900 & SIGTRL & Non-fuel otr \\
\hline 0 & 4653 & 18 & SBTRL & Base $\sigma_{t r}(9 /$ region $)$ \\
\hline 0 & 4671 & 18 & SBAL & Base $\sigma_{\text {a }}$ \\
\hline 0 & 4689 & 18 & SBTRL & Base $\sigma_{\text {tr }}$ \\
\hline 0 & 4707 & 72 & SIGBL & Base transfer matrix ( $36 /$ region) \\
\hline 0 & 4779 & 30 & BS I G A L & $\begin{array}{l}\text { Fuel } \bar{\sigma} \text { (input only with non- } \\
\text { operative SIGMA) }\end{array}$ \\
\hline 0 & 3809 & 100 & BSIGAL & $\begin{array}{l}\text { Non-fuel } \bar{\sigma}_{a} \text { (input only with } \\
\text { non-operative SIGMA) }\end{array}$ \\
\hline 0 & 4909 & 30 & BS IGFL & $\begin{array}{l}\text { Fuel } \bar{\sigma}_{f} \text { (input only with non- } \\
\text { operative SIGMA) }\end{array}$ \\
\hline 0 & 4939 & 30 & BSINUL & $\begin{array}{l}\text { Fuel } \overline{v \sigma}_{\text {f }} \text { (input only with non- } \\
\text { operative SIGMA) }\end{array}$ \\
\hline 2 & 4969 & 30 & NAME & Fuel isotope name (six characters) \\
\hline 2 & 4999 & 100 & NAME & Non-fuel isotope name (six characters) \\
\hline 1 & 5940 & & NMAX 2 & 30 plus index of last isotope \\
\hline 1 & 5950 & & I I & Iodine-135 index \\
\hline 1 & 5951 & & $I \times E$ & Xenon-135 index \\
\hline 1 & 5952 & & I S M & Samarium-149 index \\
\hline 1 & 5954 & & KGEOM & Geometry. $\quad \begin{aligned} 0 & =\text { Slab } \\
1 & =\text { Cylinder }\end{aligned}$ \\
\hline 1 & 5955 & & NBND & Boundary condition $\begin{aligned} 0 & =\text { Cell } \\
1 & =\text { Reactor } \\
2 & =\text { Infinite Homo. }\end{aligned}$ \\
\hline 1 & 5956 & & I REG & Number of regions $(1$ or 2$)$ \\
\hline 1 & 5957 & & NG & $\begin{array}{l}\text { Number of groups }(1-9) \text { (must be } 9 \\
\text { presently) }\end{array}$ \\
\hline
\end{tabular}




\begin{tabular}{|c|c|c|c|}
\hline Format & $\begin{array}{l}\text { Array } \\
\text { Location Size } \\
\end{array}$ & Name & Comments \\
\hline 1 & 5958 & NACTF & Number of actual fuel $(1-15)$ \\
\hline 1 & 5959 & NACTI & $\begin{array}{l}\text { Number of numerically analyzed } \\
\text { non-fuels }+15\end{array}$ \\
\hline 1 & 5960 & NFUEL & Number of accounting fuels $(1-30)$ \\
\hline 1 & 5961 & NMAX & NACTI +15 \\
\hline 0 & 5964 & HEIGHT & Reactor "Height" \\
\hline
\end{tabular}




\section{TABLE 1}

\section{CHAIN LINK IDENTIFICATION}

\begin{tabular}{|c|c|}
\hline Chain Link & Program Name \\
\hline 1 & COMBO \\
\hline 2 & 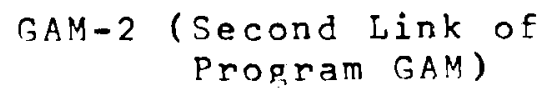 \\
\hline 3 & TEMPEST \\
\hline 4 & $\begin{aligned} \text { GAM-1 } & \text { First Link of } \\
& \text { Program GAM) }\end{aligned}$ \\
\hline 5 & HFN \\
\hline 6 & $S I G M A-3 H$ \\
\hline 7 & $S I G M A-3 C$ \\
\hline 8 & $\operatorname{CALX}$ \\
\hline 9 & KONROL \\
\hline 10 & SLOPE \\
\hline 11 & SCHWAC \\
\hline 12 & $\begin{aligned} & \text { HRG-2 } \text { (Second Link of } \\
& \text { Program HRG) }\end{aligned}$ \\
\hline 14 & $\begin{aligned} & \text { HRG-1 } \text { (First Link of } \\
& \text { Program HRS) }\end{aligned}$ \\
\hline
\end{tabular}


TABLE 2

\section{GROUP ENERGY BOUNDARIES FOR CALX}

Group No.

9

8

7

6

5

4

3

2

1
Boundary Energies (ev) (Lower)

0.0

0.683

2.38

10.68

$1.01 \times 10^{2}$

$1.23 \times 10^{3}$

$1.17 \times 10^{4}$

$1.11 \times 10^{5}$

$1.05 \times 10^{6}$
(Upper)

0.683

2.38

10.68

$1.01 \times 10^{2}$

$1.23 \times 10^{3}$

$1.17 \times 10^{4}$

$1.11 \times 10^{5}$

$1.05 \times 10^{6}$

$10.0 \mathrm{MeV}$

\section{Remarks}

Thermal Group

Epithermal Group

"

"

"

11

"

"

" 


\section{INPUT LOCATIONS FOR ISOTOPES OF THE JBURN ARRAY}

Each isotope of the JBURN array of CALX occupies four locations, one for each of four owners. An entry $(1,2,3$, or 4$)$ in either of these four locations will signify that this isotope is to be used in the burnup calculation. The mapnitude of the entry specifies which of the four owners will get the decay and cadture products of this isotope. The location that this entry occupies indicates which owner owns the isotope.

\section{Example: A 3 entered in Location 130 indicates that Owner 2 owns the isotope U238, and that Owner 3 will get the capture and decay products.}

NOTE: For DBURN array add 700 to the indut locations in this table.

\begin{tabular}{|c|c|c|c|c|}
\hline $\begin{array}{l}\text { Is ot ope } \\
\text { Name } \\
\end{array}$ & $\begin{array}{c}\text { Owner } 1 \\
\text { Location No. } \\
\end{array}$ & $\begin{array}{l}\text { Owner } 2 \\
\text { Location No. } \\
\end{array}$ & $\begin{array}{l}\text { Owner } 3 \\
\text { Location No. } \\
\end{array}$ & $\begin{array}{l}\text { Owner } 4 \\
\text { Location No. }\end{array}$ \\
\hline-- & 41 & 42 & 43 & 44 \\
\hline$T h-227$ & 45 & 46 & 47 & 48 \\
\hline$T h-228$ & 49 & 50 & 51 & 52 \\
\hline$T h-229$ & 53 & 54 & 55 & 56 \\
\hline$T h-230$ & 57 & 58 & 59 & 60 \\
\hline$T h-231$ & 61 & 62 & 63 & 64 \\
\hline$T h-232$ & 65 & 66 & 67 & 68 \\
\hline$T h-234$ & 69 & 70 & 71 & 72 \\
\hline$P a-229$ & 73 & 74 & 75 & 76 \\
\hline $\mathrm{Pa}-230$ & 77 & 78 & 79 & 80 \\
\hline$P a-231$ & 81 & 82 & 83 & 84 \\
\hline$P a-232$ & 85 & 86 & 87 & 88 \\
\hline$P a-233$ & 89 & 90 & 91 & 92 \\
\hline$P a-234$ & 93 & 94 & 95 & 96 \\
\hline
\end{tabular}


TABLE 3 (cont)

\begin{tabular}{|c|c|c|c|c|}
\hline $\begin{array}{l}\text { Is ot ope } \\
\text { Name } \\
\end{array}$ & $\begin{array}{c}\text { Owner } 1 \\
\text { Location No. }\end{array}$ & $\begin{array}{c}\text { Owner } 2 \\
\text { Location No. }\end{array}$ & $\begin{array}{l}\text { Owner } 3 \\
\text { Location No. }\end{array}$ & $\begin{array}{c}\text { Owner } 4 \\
\text { Location No. }\end{array}$ \\
\hline$U-230$ & 97 & 98 & 99 & 100 \\
\hline$U-231$ & 101 & 102 & 103 & 104 \\
\hline$U-232$ & 105 & 106 & 107 & 108 \\
\hline$U-233$ & 109 & 110 & 111 & 112 \\
\hline$U-234$ & 113 & 114 & 115 & 116 \\
\hline$U-235$ & 117 & 118 & 119 & 120 \\
\hline$U-236$ & 121 & 122 & 123 & 124 \\
\hline$U-237$ & 125 & 126 & 127 & 128 \\
\hline$U-238$ & 129 & 130 & 131 & 132 \\
\hline$N p-234$ & 133 & 134 & 135 & 136 \\
\hline$N p-235$ & 137 & 138 & 139 & 140 \\
\hline$N p-236$ & 141 & 142 & 143 & 144 \\
\hline$N_{p}-237$ & 145 & 146 & 147 & 148 \\
\hline$N_{p}-238$ & 149 & 150 & 151 & 152 \\
\hline$N p-239$ & 153 & 154 & 155 & 156 \\
\hline$P u-236$ & 157 & 158 & 159 & 160 \\
\hline$P u-237$ & 161 & 162 & 163 & 164 \\
\hline$P u-238$ & 165 & 166 & 167 & 168 \\
\hline $\mathrm{Pu}-239$ & 169 & 170 & 171 & 172 \\
\hline$P u-240$ & 173 & 174 & 175 & 176 \\
\hline$P u-241$ & 177 & 178 & 179 & 180 \\
\hline $\mathrm{Pu}-242$ & 181 & 182 & 183 & 184 \\
\hline$A m-240$ & 185 & 186 & 187 & 188 \\
\hline$A m-241$ & 189 & 190 & 191 & 192 \\
\hline$A m-242$ & 193 & 194 & 195 & 196 \\
\hline$A m-243$ & 197 & 198 & 199 & 200 \\
\hline
\end{tabular}




\section{REFERENCES}

1. R. R. Shudde and J. Dyer. NAA Program Descriotion, TEMPEST, A Neutron Thermalization Code. September, 1960.

2. J.L. Carter, Jr. Private Communication.

3. G. D. Joanou and J. S. Dudek. GAM-I, A Consistent P Multi-Group Code for the Calculation of Fast Neutron Spectra and Multi-Group Constants, GA-1850. June, I961

4. J. R. Lilley. Computer Code HFN - A Multi-Group, MultiRegion Neutron Diffusion Theory in One-Space Dimension, HW-71545. October, 1961

5. D. R. Marr. Private Communication.

6. D. D. Matsumoto. LISTIV, A Fortran IV Generalized Input Routine, BNWL-41. March, 1965.

7. E. L. Kelley, Jr. SIGMA-3 Library, HW-81691. June, 1964 .

8. E. L. Kelley, Jr. USERS Manual For HFN and Calx Chain, $\mathrm{HW}-80968$. March, 1964 . 


\section{DISTRIBUTION}

No. of

Copies

Division of Technical Information Extension

Douglas United Nuclear

R. Nilson

G. F. Owsely

General Electric Company

W. S. Nechodom

Isochem Inc.

R. D. Carter

Richland Operations Office

P. G. Holsted

University of California, Livermore

Dr. James Hadley

Bat te $11 \mathrm{e}$-Northwest

D. N. Adrian

C. L. Bennett

R. A. Bennett

G. L. Busse1man

J. L. Carter, Jr.

F. G. Daws on

D. E. Deonigi

B. H. Duane

E. A. Eschbach

R. A. Harris

C. M. Heeb

R. E. Heineman

P. L. Hofmann

R. H. Holeman

U. P. Jenquin

E. L. Kelley, Jr.

D. D. Lanning

R. C. Liikala
C. W. Lindenmeier

D. R. Marr

D. D. Matsumoto

W. W. Porata

W. L. Purce 11

J. J. Regimbal

C. R. Richey

L. C. Schmid

G. D. Seybold

G. L. Simmons

R. I. Smith

J. R. Worden

Technical Information Files (5)

Technical Publications

(2) 